\title{
Structural Dimensions, Fabrication, Materials, and Operational History for Types I and II Waste Tanks
}

by

B. J. Wiersma

Westinghouse Savannah River Company

Savannah River Site

Aiken, South Carolina 29808

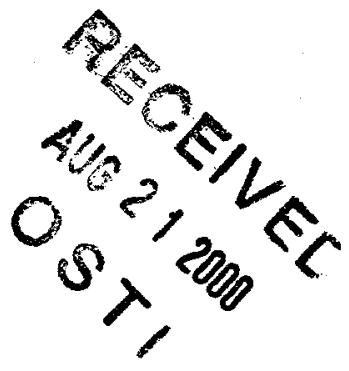

P. E. Zapp

This paper was prepared in connection with work done under the above contract number with the U.S. Department of Energy. By acceptance of this paper, the publisher and/or recipient acknowledges the U. $S$. Government's right to retain a nonexclusive, royalty-free license in and to any copyright covering this paper, along with the right to reproduce and to authorize others to reproduce all or part of the copyrighted paper. 


\section{DISCLAIMER}

This report was prepared as an account of work sponsored by an agency of the United States Government. Neither the United States Government nor any agency thereof, nor any of their employees, makes any warranty, express or.implied, or assumes any legal liability or responsibility for the accuracy, completeness, or usefulness of any information, apparatus, product or process disclosed, or represents that its use would not infringe privately owned rights. Reference herein to any specific commercial product, process or service by trade name, trademark, manufacturer, or otherwise does not necessarily constitute or imply its endorsement, recommendation, or favoring by the United States Government or any agency thereof. The views and opinions of authors expressed herein do not necessarily state or reflect those of the United States Government or any agency thereof.

This report has been reproduced directly from the best available copy.

Available for sale to the public, in paper, from: U.S. Department of Commerce, National Technical Information Service, 5285 Port Royal Road, Springfield, VA 22161, phone: (800) 553-6847,

fax: (703) 605-6900

email: orders@ntis.fedworld.gov

online ordering: http://www.ntis.gov/ordering.htm

A vailable electronically at http://www.doe.gov/bridge A vailable for a processing fee to U.S. Department of Energy and its contractors, in paper, from: U.S. Department of Energy, Office of Scientific and Technical Information, P.O. Box 62, Oak Ridge, TN 37831-0062, phone: (865)576-8401, fax: (865)576-5728

email: reportseadonis.osti.gov 


\section{DISCLAIMER}

Portions of this document may be illegible in electronic image products. Images are produced from the best available original document. 


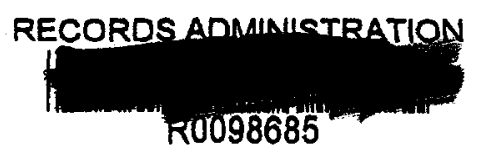

\title{
Structural Dimensions, Fabrication, Materials and Operational History for Types I and II Waste Tanks (U)
}

\author{
B. J. Wiersma \\ P. E. Zapp \\ Savannah River Technology Center \\ Strategic Materials Department \\ Materials Technology Section
}

Publication Date: October, 1998

\section{Westinghouse Savannah River Company Savannah River Site Aiken, SC 29808}

This document was prepared in connection with work done under Contract No. DE-AC09-89SR18035 with the U. S. Department of Energy. By acceptance of this document, the publisher and/or recipient acknowledges the U. S. Government's right to retain a nonexclusive, royalty-free license in and to any copyright covering this document, along with the right to reproduc and authorize others to reproduce all or part of the copyrighted material. 


\section{$S M T D$}

Strategic Materials Technology Department

Keywords: Structural Integrity, High Level

Waste

Retention - Permanent

\section{Structural Dimensions, Fabrication, Materials and Operational History for Types I and II Waste Tanks (U)}

B. J. Wiersma

P. E. Zapp

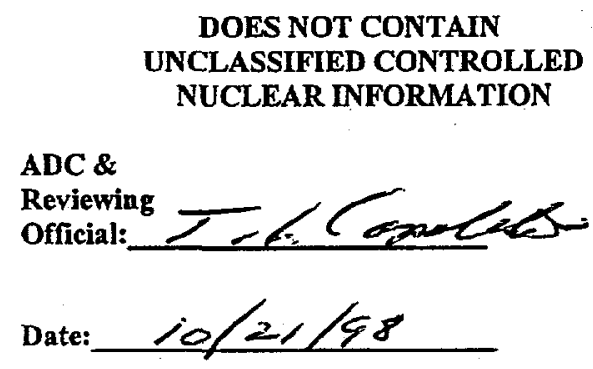

SRTC SAVANNAH RIVER TECHNOLOGY CENTER, AIKEN, SC 29808 Westinghouse Savannah River Company Prepared for the U. S. Department of Energy under Contract DE-AC09-89SR18035 
WSRC-TR-98-00373 (U)

APPROVALS

Bunce/Drems

B. J. Wiersma, Author

Materials Applications \& Corrosion Technology Group

MATERIALS TECHNOLOGY SECTION

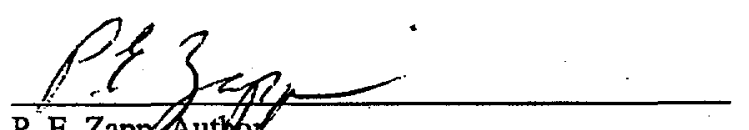

P. E. Zappa Auth or

Materials Applications \& Corrosion Technology Group MATERIALS TECHNOLOGY SECTION

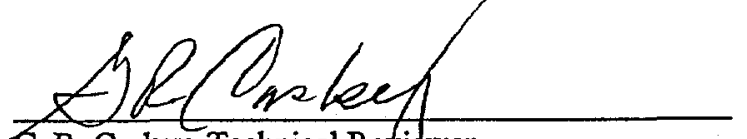

G. R. Caskey, Technical Reviewer

Materials Applications \& Corrosion Technology Group MATERIALS TECHNOLOGY SECTION

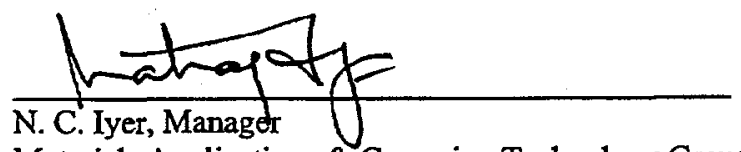

Materials Applications \& Corrosion Technology Group MATERIALS TECHNOLOGY SECTION

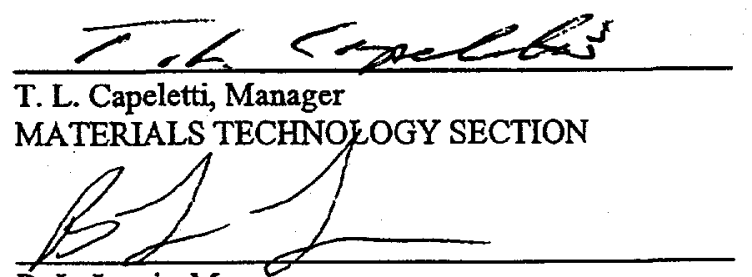

B. L. Lewis, Manager

Concentration, Storage, and Transfer Engineering
Date: $10-19-98$

Date: $10-19-98$

Date: $10-19-98$

Date: $10-19-98$

Date: $10 / 2 / 1 / 48$.

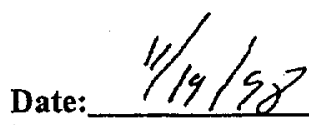


Structural Dimensions, Fabrication, Materials and Operational History for Types I and II Waste Tanks

\subsection{Introduction and Summary}

Radioactive waste is confined in 48 underground storage tanks at the Savannah River Site (SRS). The waste will eventually be processed and transferred to other site facilities for stabilization. Based on waste removal and processing schedules, many of the tanks, including those with flaws and/or defects, will be required to be in service for another 15 to 20 years. Until the waste is removed from storage, transferred, and processed, the materials and structures of the tanks must maintain a confinement function by providing a leak-tight barrier to the environment and by maintaining acceptable structural stability during design basis event (DBEs) which include loadings from both normal service and abnormal conditions.

Recently the presence of a 12 to 15 inch flaw below the middle girth weld in Tank 15 has been confirmed [1]. This tank currently contains "dry" sludge at a height that is approximately 70 inches below the level of the flaw. Therefore, no waste is currently leaking through this crack. However, this crack is the longest observed crack in the SRS waste tanks. The shape of the crack, which moves in an arc away from the weld, was also different than previously observed flaws that were perpendicular to the weld.

A tank life management program was developed to assess the near-term impact of the crack in Tank 15 and to address the general impact to operation of the Type I and II tanks [2]. The program will evaluate confinement (structural stability and leak tightness) of the Type I and II waste tanks throughout their service life. The activities involved in this program include: a) development of inspection criteria and equipment for Tank 15, b) preparation of a database report that assess the past and present condition of the Tank 15 in particular and the Type I and II tanks in general, c) an assessment of the degradation mechanism that occurred in Tank 15, d) stress analyses for normal, abnormal, and seismic events, e) flaw stability analysis for Tank 15 in particular and the Type I and II tanks, in general, f) determination of fill limits for tanks with flaws, g) an assessment of various tank repair techniques, and $h$ ) determination of inspection frequencies. This document fulfills the requirements of item $b$ ) and provides necessary inputs into the other parts of the program.

The document is divided into five sections. The first section covers the original design requirements, codes, and site specifications that were used to construct the tanks. These requirements include welding procedures and qualifications, post-fabrication inspections, etc. The next section provides information on the geometric configuration of the waste tanks. The third section reviews visual observations of the tank wall that have been made through the years. These include photographs from pre-service inspections and in-service inspections including the observations on the recent flaw in Tank 15. This section also includes inspection requirements for the current life management program. The next section discusses the mechanical and fracture properties of the material of construction. These data are crucial for the flaw stability analysis. The final section of this document 
will focus on the operational history of Tank 15. This information will be utilized during the degradation assessment.

\subsection{Tank Design Requirements, Construction Codes, and Site Specifications}

\subsection{Type I Tanks}

All work in connection with the fabrication, erection, welding and testing of the Type I tanks conformed to the Rules for Construction of Unfired Pressure Vessels, Section VIII of the ASME Boiler Construction Code 1949 [3]. The steel sub-contractor furnished the materials, labor, and equipment and performed certain inspections in connection with the construction of the tanks.

The plates that formed the steel tank were assembled by welding in accordance with the Code where applicable. The electrodes utilized for welding complied with AWS-ASTM "Specification for Iron and Steel Arc Welding Electrodes." Welding procedures and welding operator qualifications were in compliance with Section IX of the ASME Code. Given that repair welds were made with an E6010 electrode it is probable that the tank welds were made with a similar electrode.

Surfaces to be welded were cleaned so that they were free of loose scale, clay, rust, grease, paint, and other foreign material. Joint surfaces were smooth and free of defects. Each layer of metal on multi-layer welds was cleaned of slag before the next layer of weld material was applied. The weld was cleaned between passes by either chipping or machining. Cleaning the surface by gas gouging was not permitted. Intermittent welding was not allowed: Defects in welds were chipped, flame gouged, or otherwise machined out until sound metal was reached on all sides. The cavity was then filled with new metal. The welding edges were uniform and smooth and free of slag.

The initial wall thickness of the top and bottom plates was 0.5 inch. The top and bottom plates were laid out and joined by welding using a sequence that minimized buckling, and for the bottom plates also ensured minimum variation in slope and or variation and/or elevation particularly under the column base plates. No buckle greater than 1 inch, or slope of the buckle greater than 0.33 inch per foot was allowed. The offset in adjoining plates was not allowed to be greater than $10 \%$ of the plate thickness.

The lower knuckle plate was made from a 0.5 inch thick plate that was curved in two directions by hot forming. The radius of the lower knuckle was one foot. The upper knuckle plate was made from 0.563 inch plate that had been curved by hot forming. The radius of the upper knuckle was four feet. The curved plates were sub-assembled in groups of not less than four pieces prior to being attached to either the top or bottom plates. The buckle in a 2 foot arc did not exceed 0.312 inch as formed and before welding. The offset between adjoining plates was not allowed to exceed $10 \%$ of the plate thickness. 
The initial wall thickness for the side plates was 0.5 inch. The side plates were assembled in a manner that minimized distortion due to shrinkage and eliminated kinks at the seams and vertical joints. The deviation from a true circle did not exceed 1 inch in an $80^{\circ}$ arc length. The offset between adjoining plates was not allowed to exceed $10 \%$ of the plate thickness.

The outside of the primary steel wall for all Type I tanks was painted. Two types of paint were utilized: a) bituminous and b) oil-based pigment type. The bituminous paint contained gilsonite asphalt and adhesive synthetic resins in a processed oil vehicle. The softening temperature of the asphalt paint was to exceed $220^{\circ} \mathrm{F}$. After application of a primer, two brush coats of this paint were applied to the bottom surface of the tank and the exterior of the steel pan. The oil-based pigment paint contained a chromate corrosion inhibitor and iron oxide pigments of micaceous hematite. The paint was suitable for steel surfaces subject to a maximum temperature of $220^{\circ} \mathrm{F}$. Two finish coats of this paint were applied to the remainder of the tank primary and the interior of the steel pan.

The interior of the primary steel wall of all the Type I tanks was coated with Shell VPI220 Rust Inhibitor ${ }^{\mathrm{TM}}$. The spray solution consisted of 3.5 pounds of VPI-220 per gallon of water in order to produce a mixture that would provide approximately 0.5 grams of inhibitor per square foot of surface. Following the application of the mixture, the floor of the tank was to be dried and re-sprayed with VPI-220. The tank was then to be sealed off to prevent water intrusion. If a vent was necessary, a bag of dry VPI-220 was to be put into the vent line.

The contractor was responsible for the final inspection of the tanks. The types of inspections were visual, radiographic and leak testing. All welds were visually inspected upon completion of the weld and/or after each pass if requested. The welds were to be approved before radiographic inspection could begin. All welds affecting the ability of the tank to retain liquids or gases were radiographed by methods that met the accuracy required by the Code. This included welds to and in manholes, nozzles, sleeves, or couplings attached to, or penetrating the steel shell. Radiographic inspection of the pan was not required. The length of weld covered by each radiograph was not to exceed 15 inches. A center punch mark was made at the ends of each radiographic exposure location and the identifying letters or numbers were stenciled in the base metal adjacent to the weld at the center of each exposure location. The pan, the tank bottom, and the completed tank were subjected to a water test to determine if the structure was leak tight. The pan and tank bottoms were vacuum leak tested using 2.5 psig differential pressure. The sides of the pan were tested by filling the pan to the top with water and inspecting for leaks. The completed tank was water tested to a head pressure not less than 9 inches or greater than 1 foot above the top of the tank. All pipes and openings were blanked during the test, except for one pipe that acted as an overflow. After 24 hours, the tank was inspected for leaks.

Temporary attachments were utilized frequently during the construction stages. An example of a temporary attachment is hooks that were welded to the side of tanks in order 
to hang lanterns or extension cords. These attachments were to be removed without gouging, burning, or tearing the carbon steel plate.

\subsection{Type II Tanks}

All work in connection with the fabrication, erection, welding and testing of the Type II tanks conformed to the Rules for Construction of Unfired Pressure Vessels, Section VIII of the ASME Boiler Construction Code 1952 [4]. The electrodes utilized for welding complied with AWS-ASTM "Specification for Iron and Steel Arc Welding Electrodes." Welding procedures and welding operator qualifications were in compliance with Section LX of the ASME Code.

Two welding procedures were utilized for the Type II waste tanks: shielded metal arc welding (SMAW) and submerged arc welding (SAW) [5]. Table 1 summarizes the tank location where each process was applied and the electrodes that were utilized. The SMAW technique was employed on vertical on vertical and difficult to reach areas, while the SAW technique was utilized for the horizontal bottom and roof plates. A description of the electrodes follows:

Fleet Weld \#5 - The trade name that Lincoln Electric used for the E6010 class electrode. These electrodes are useful for dirty, rusty, painted or plated steel that cannot be completely cleaned. The $\mathrm{E}$ in the class name represents an arc welding electrode, while the 60 indicates a tensile strength of $60 \mathrm{ksi}$. The 1 indicates that the electrode is for use in all positions (i.e., flat or vertical) and the 0 indicates a DC current with the electrode being positive. Hobart and Champion evidently also provided E6010 class electrodes for the project.

Lincolnweld L60 - The trade name that Lincoln Electric used for an EL 12 class electrode. The weld is a low carbon, low manganese, low silicon general purpose electrode and was used primarily for multiple pass welding of steel plates less than 1 inch thick. The flux that was utilized in conjunction with this electrode was Linde Automatic Flux 50 Melt. No details on the description of this product were found.

Surfaces to be welded were cleaned so that they were free of loose scale, clay, rust, grease, paint, and other foreign material. Joint surfaces were smooth and free of defects. Each layer of metal on multi-layer welds was cleaned of slag before the next layer of weld material was applied. The weld was cleaned between passes by either chipping or machining. Cleaning the surface by gas gouging was not permitted. Intermittent welding was not allowed. Defects in welds were chipped, flame gouged, or otherwise machined out until sound metal was reached on all sides. The cavity was then filled with new metal. The welding edges were uniform and smooth and free of slag.

The initial wall thickness of the top and bottom plates was 0.5 inch. The top and bottom plates were laid out and joined by welding using a sequence that minimized buckling, and for the bottom plates also ensured minimum variation in slope and or variation and/or elevation particularly under the column base plates. No buckle greater than 1 inch, or 
slope of the buckle greater than 0.33 inch per foot was allowed. The offset in adjoining plates was not allowed to be greater than $10 \%$ of the plate thickness.

Table 1. Welding Procedures and Electrodes Utilized to Construct Type II Tanks

\begin{tabular}{|c|c|c|}
\hline \multirow{2}{*}{$\frac{\text { Location }}{\text { Bottom Plates }}$} & Technique & Electrode \\
\hline & $\begin{array}{l}\text { SMAW (flat butt weld) } \\
\text { SAW (flat butt weld) }\end{array}$ & $\begin{array}{l}\text { Fleet Weld } \# 5-1 / 8^{\prime \prime}, 5 / 32^{\prime \prime} \\
3 / 16^{\prime \prime} \\
\text { Lincoln Automatic L60 - 5/32", } \\
3 / 16^{\prime \prime} \\
\text { Linde Automatic Flux } 50 \text { Melt }\end{array}$ \\
\hline $\begin{array}{l}\text { Bottom Knuckle Plate to Bottom } \\
\text { Plates }\end{array}$ & $\begin{array}{l}\text { SMAW (flat butt weld) } \\
\text { SAW (flat butt weld) }\end{array}$ & $\begin{array}{l}\text { Fleet Weld } \# 5-1 / 8 ", 5 / 32 ", \\
\text { 3/16" } \\
\text { Lincoln Automatic L60-5/32", } \\
\text { 3/16" } \\
\text { Linde Automatic Flux } 50 \text { Melt }\end{array}$ \\
\hline $\begin{array}{l}\text { Vertical Welds for Bottom } \\
\text { Knuckle Plates }\end{array}$ & $\begin{array}{l}\text { SMAW (flat and vertical butt } \\
\text { weld) }\end{array}$ & $\begin{array}{l}\text { Hobart, Lincoln, or Champion } \\
\text { E6010-5.32", 3/16" }\end{array}$ \\
\hline Shell to Bottom Knuckle Plate & SMAW (horizontal butt weld) & Hobart E6010 - 3/16" \\
\hline Shell Horizontal Seam & SMAW (horizontal butt weld) & Hobart E6010 - 3/16" \\
\hline Shell Vertical Seam & SMAW (vertical butt weld) & $\begin{array}{l}\text { Hobart, Lincoln, or Champion } \\
\text { E6010-5/32" }\end{array}$ \\
\hline Roof Knuckle Plate to Shell & SMAW (horizontal butt weld) & Hobart E6010 - 3/16" \\
\hline $\begin{array}{l}\text { Vertical Welds for Roof Knuckle } \\
\text { Plates }\end{array}$ & $\begin{array}{l}\text { SMAW (flat and vertical butt } \\
\text { weld) }\end{array}$ & $\begin{array}{l}\text { Hobart, Lincoln, or Champion } \\
\text { E6010-5.32", 3/16" }\end{array}$ \\
\hline $\begin{array}{l}\text { Roof Knuckle Plates to Roof } \\
\text { Plates }\end{array}$ & $\begin{array}{l}\text { SMAW (flat butt weld) } \\
\text { SAW (flat butt weld) }\end{array}$ & $\begin{array}{l}\text { Fleet Weld } \# 5-1 / 8 ", 5 / 32 ", \\
3 / 16 " \\
\text { Lincoln Automatic L60 - 5/32", } \\
\text { 3/16" } \\
\text { Linde Automatic Flux 50 Melt }\end{array}$ \\
\hline Roof Plates & $\begin{array}{l}\text { SMAW (flat butt weld) } \\
\text { SAW (flat butt weld) }\end{array}$ & $\begin{array}{l}\text { Fleet Weld \#5-1/8", 5/32", } \\
\text { 3/16" } \\
\text { Lincoln Automatic L60-5/32", } \\
\text { 3/16" } \\
\text { Linde Automatic Flux 50 Melt }\end{array}$ \\
\hline $\begin{array}{l}\text { Column Cone Plates to Roof } \\
\text { Plates }\end{array}$ & $\begin{array}{l}\text { SMAW (flat butt weld) } \\
\text { SAW (flat butt weld) }\end{array}$ & $\begin{array}{l}\text { Fleet Weld \#5-1/8", 5/32", } \\
3 / 16 " \\
\text { Lincoln Automatic L60 - 5/32", } \\
\text { 3/16" } \\
\text { Linde Automatic Flux 50 Melt }\end{array}$ \\
\hline Column Cone Plates & $\begin{array}{l}\text { SMAW (flat and vertical butt } \\
\text { weld) }\end{array}$ & $\begin{array}{l}\text { Hobart, Lincoln, or Champion } \\
\text { E6010-5.32", 3/16" }\end{array}$ \\
\hline Column Cone to Column & SMAW (horizontal butt weld) & Hobart E6010 - 3/16" \\
\hline
\end{tabular}

The lower knuckle plate was made from a 0.875 inch thick plate that was curved in two directions by hot forming. The radius of the lower knuckle was one foot. The upper knuckle plate was made from 0.563 inch plate that had been curved by hot forming. The 
radius of the upper knuckle was four feet. The curved plates were-sub-assembled in groups of not less than four pieces prior to being attached to either the top or bottom plates. The buckle in a 2 foot arc did not exceed 0.312 inch as formed and before welding. The offset between adjoining plates was not allowed to exceed $10 \%$ of the plate thickness.

The initial wall thickness for the side plates was 0.625 inch. The side plates were assembled in a manner that minimized distortion due to shrinkage and eliminated kinks at the seams and vertical joints. The deviation from a true circle did not exceed linch in an $80^{\circ}$ arc length. The offset between adjoining plates was not allowed to exceed $10 \%$ of the plate thickness.

The exterior of the primary walls does not appear to have been painted. However, the interior walls likely were coated with the VPI-220 rust inhibitor. The requirements for the inhibitor were the same as for the Type I tanks.

The contractor was responsible for the final inspection of the tanks. The types of inspections were visual, radiographic and leak testing. All welds were visually inspected upon completion of the weld and/or after each pass if requested. The welds were to be approved before radiographic inspection could begin. All welds affecting the ability of the tank to retain liquids or gases were radiographed by methods that met the accuracy required by the Code. This included welds to and in manholes, nozzles, sleeves, or couplings attached to, or penetrating the steel shell. Radiographic inspection of the pan was not required. The length of weld covered by each radiograph was not to exceed 15 inches. A center punch mark was made at the ends of each radiographic exposure location and the identifying letters or numbers were stenciled in the base metal adjacent to the weld at the center of each exposure location. The pan, the tank bottom, and the completed tank were subjected to a water test to determine if the structure was leak tight. The pan and tank bottoms were vacuum leak tested using 2.5 psig differential pressure. The sides of the pan were tested by filling the pan to the top with water and inspecting for leaks. The top of the tank was vacuum leak tested using 2.5 psig differential pressure. The completed tank was water tested to a head not less than level with the top, or greater than 3" above the top of the tank. All pipes and openings were blanked during the test, except for one pipe that acted as an overflow. After 24 hours, the tank was inspected for leaks.

Temporary attachments were utilized frequently during the construction stages. An example of a temporary attachment is hooks that were welded to the side of tanks in order to hang lanterns or extension cords. These attachments were to be removed without gouging, burning, or tearing the carbon steel plate. 


\subsection{Dimensions of Type I and II Tanks}

\subsection{Type I Tank Dimensions}

Tanks 1-12 are designated as Type I tanks. Tanks 1-8 are in F-Area, while tanks 9-12 are in H-Area. Figure 1 shows a schematic drawing of the Type I tanks. The primary tank is a closed cylinder that is 75 feet in diameter and 24.5 feet high for a total capacity of 750,000 gallons [1]. The top and bottom plates are constructed of 0.5 inch thick steel plate and are joined to the sidewall by curved knuckle plates. The sidewall is also made of 0.5 inch thick steel plate. The primary tank is set within a circular pan of 0.5 inch thick steel that is 5 feet deep and 5 feet larger in diameter that the primary tank. The tank and pan are set on top of a 30 inch thick concrete base slab and are enclosed by a cylindrical 22 inch thick reinforced concrete wall and flat concrete roof. There are twelve 2 foot diameter concrete columns within the primary tank to support the roof. Each column has a flared capital and is encased in 0.5 inch thick steel.plate. A 9 foot layer of earth was place over the tanks for radiation shielding. Inspection of the exterior wall of the primary is limited to $25 \%$ through the four risers that provide access to the annulus.

\subsection{Type II Tank Dimensions}

Tanks 13-16 are designated as Type II tanks and are all located in H-Area. Figure 2 shows a schematic drawing of the Type $I I$ tanks. The primary tank is 85 feet in diameter and 27 feet high for a total capacity of $1,030,000$ gallons [1]. The primary consists of two concentric cylinders assembled with a flat bottom and top to form a toroidal shape. The steel plate thickness at different locations is shown in Table 2. The top and bottom are joined to the outer cylinder by rings of curved knuckle plates. The inner cylinder is flared at the top to accommodate the roof support column. This cylinder is joined to the flat steel top with a continuous butt weld. The base of the column was not required to be welded to the bottom plates, however, a continuous tack weld may have been utilized during erection of the column [6]. The primary tank is set on a 1 inch bed of sand within a circular pan of 0.5 inch thick steel plate, 5 feet deep and 5 feet larger than the diameter of the primary tank. The tank and pan are surrounded by a cylindrical reinforced concrete enclosure with a 33 inch thick wall and a 45 inch thick flat roof. In addition to the 4 annulus risers, 10 to 14 access openings have been constructed for inspection purposes. These ports allow 73 to $96 \%$ of the exterior primary wall to be inspected.

Table 2. Steel Wall Thickness for Type II Tanks

\begin{tabular}{cc} 
Plate & Thickness, inch \\
\hline Top and bottom & 0.5 \\
Upper knuckle & 0.56 \\
Wall & 0.625 \\
Lower knuckle & 0.875 \\
\hline
\end{tabular}




\subsection{Inspection Program for Types I and II Tanks}

\section{I Pre-Service Inspections of Tanks}

Records for the pre-service inspections on three tanks, 4,6 , and 15 were located. Although there were some differences in the specifics, there were certain consistencies that were evident. Primarily, the tanks were observed to have several pits, gouges and dents present during the pre-service inspection. This reflects the fact that the construction specifications that were used for the Type I (Specification 3206) and the Type II (Specification 3537) did not require that the tank be inspected in areas where there was no welding. The results of these inspections are discussed below.

\subsection{Tank 15 Pre-Service Inspection [7,8]}

The preliminary visual inspection of Tank 15 was conducted in August of 1959 by the Engineering Assistance Section (equivalent to the Materials Consultation Group), Separations Technology and Separations Department. The inspection included the tank bottom and the sides to a height of 6 feet. The observations made relative to the tank primary are summarized below.

General Appearance

Interior Tank

1. Normal rust formation and peeling of mill scale.

2. Where excess Shell "VPI" - 220 Rust Inhibitor was placed on floor plates, the rust formation was retarded appreciably.

Exterior Tank

1. Normal rust formation and peeling of mill scale. The outer walls were not painted. 2. The pan also had normal rust formation and peeling of mill scale. There also was a thin scale of cement over most of the knuckle plates. There were also numerous patch welds.

Specific Observations

Interior Tank

1. Severe pitting of 0.5 inch floor plates under deposits containing iron oxide and what appeared to be flux from submerged arc welding. Pits were 0.125 inch deep by 0.25 inch in diameter. (See Figure 3)

2. Punch marks made for radiographic orientation were adjacent to seam welds. The marks were 0.05 to 0.07 inch deep. Stamp marks made for radiographic orientation were 0.015 deep. There were approximately 1500 punch marks. (See Figure 4)

3. Hooks for holding extension cords were made by welding carbon steel welding electrodes to the side of the tank. At least two of these resulted in a weld crater in the 0.625 inch side plates that was 0.075 inch deep. (See Figure 5)

4. Numerous metal-arc patch welds (1-6 inches long) on floor, side and knuckle plates. These weld beads were made to fill in where the base metal was removed due to chipping loose of alignment "fish -plates" and various other braces that were welded to the tank plates during construction. (See Figure 4) 
5. The resulting groove from the partially ground-out seam weld was approximately 0.02 inch deep and 18 inches long. (See Figure 6)

6. Welds were inspected utilizing the magnetic particle technique that was designed to detect fine cracks that would be undetected by radiography. This type of inspection was used on $20 \%$ of the butt welds on the bottom of the tank and $25 \%$ of the butt welds on the side of the tank to a height of 6 feet. Dye penetrant testing was performed on 30 patch welds. No flaws were detected by either of these methods.

\section{Exterior Tank}

1. Punch marks adjacent to welds are the same as on the inside of the tank.

2. Patch welds are present on knuckle and side plates, same as the interior of the tank.

3. Partially ground-out seam weld same as the interior, approximately 0.012 inch deep and 15 inches long.

4. 24 backup plates were placed over vertical seam welds between the knuckle plates. (See Figure 7)

5. Heavy intermittent welds were used to attach the vertical leg of angle irons to knuckle plates. (See Figure 8)

6. Severe buckle in the seam weld, about 0.5 inch per 12 inches. (See Figure 9)

None of these defects or flaws were expected to cause certain failure of the tank. However, they had the potential to concentrate stresses and serve as initiation sites for nitrate stress corrosion cracking and/or pitting. The pre-service inspection indicated many corrosion pits and fabrication defects that could have served as stress raisers. Many of these defects were greater than the specification allowed (see fabrication section). As a result of this inspection, repairs and further inspections were recommended in March of 1960. A complete visual inspection of the sides of the tank and repair of all pits and defects that had a depth greater than 0.075 inch (10-15\% of the nominal wall thickness) was to be performed. It was expected that no more than 10 of these pits or defects would be found. The weld repair procedure recommended by engineering is summarized in Table 3 . It is important to note that, like the tank, none of these weld repairs were stress-relieved. A final gas leak check was to be performed prior to filling. The tank was to be pressurized to $1 \mathrm{psig}$ with helium or freon. The annulus was then checked for a leakage rate on the order of 2 cubic feet of gas per day. It is believed that these repairs and inspections were carried out, although records were not located.

\subsubsection{Tank 4 Pre-Service Inspection [9]}

Waste Tank 4, a Type I tank, was inspected in March 1961 to determine the pre-service condition of the tank. A visual inspection was performed of the entire tank bottom, the bottom five feet of the interior sides of the tank, and the pan area within the annulus. The observations made are summarized below.

1. Many corrosion pits and a few gouges (see Figure 10) and weld undercuts, ranging from 0.04 inch to 0.09 inch in depth, were found on the interior surfaces of the tank. 
2. Three deep holes ( 0.14 inch, 0.165 inch and 0.17 inch) were burned into the 0.5 inch thick tank bottom plates with a cutting torch during removal of misplaced cooling coil braces (see Figure 11).

3. Three " $U$ " shaped attachments, welded to the interior surface of the knuckle plate, had not been removed.

4. The paint on the exterior surface of the tank wall was in good condition and had afforded excellent protection.

5. The annulus pan was in satisfactory condition. Areas of heavy rust were attributed to . rainwater in-leakage.

It was recommended that the three deep gouges be repaired by the same weld repair procedure utilized for Tank 15 . No mention was made of repairing the other gouges that were observed. It was also recommended that the " $U$ " shaped attachments be removed from the knuckle plate. No records were found to verify that these procedures were performed.

Table 3. Weld Repair Procedure

Pre-heat: None required

Preparation: $\quad$ Remove defect by grinding to sound metal. Remove all oxide, dirt, etc. from weld area before welding.

Welding Method: Metal-arc

Electrode: $\quad$ E6010 for out of position welding

E6020 for flat position welding

Current E6010, D. C. reverse polarity

Characteristics: $\quad$ E6020, D. C. straight polarity

Post-heat: None required.

Inspection: Grind weld flush with surface of plate and visually inspect for porosity, undercut, lack of fusion, cracks, etc. If defects are present grind out, re-weld and re-inspect. Check any questionable areas with the dye-penetrant inspection method.

\subsubsection{Tank 6 Pre-Service Inspection [10]}

Tank 6, another Type I tank, remained in a lay-up condition for over 10 years before it was placed in service. A reference that summarized the four pre-service inspections performed on these tanks through February of 1964 was located. 
At the time of construction (1952-53) visual and radiographic inspection of all welds were made after completion of the weld per construction Specification 3206. Certain welds were exempted among those were welds for attachment clips or hangers. Later it was observed that the most severe weld undercutting and poor fillet formation occurred at these types of welds. Specification 3206, however, did not refer to corrosion pits, dents and gouges that may be present in areas where there was no welding. Other similar tanks were found to have serious pits and/or gouges.

In September of 1953 the interior tank walls of 6 of the Type I tanks in F-Area (Tanks 1, $3,5-8$ ) were inspected to determine the degree of rust protection still remaining [11]. Inspection showed little evidence of Vapor Phase Inhibitor-220 (VPI-220) in 5 of the 6 tanks inspected. "No rusting over and above original rust was noted on the walls or bottoms of the tanks. At the bottom knuckle, scaling and possibly some increase in rust was noted. It is believed a large portion of the original protection by VPI-220 has been lost in a number of the tanks through too much ventilation and the entrance of water."

In February of 1961 an internal inspection of Tank 6 was made by EAS [12]. No mention of the extent of inspection was made, although it seems likely that it was similar to that for Tank 4, which was performed about the same time. Two significant items were identified among others: 1) Many corrosion pits (to 0.0625 inch deep) and 2) the fillet weld connecting the inlet line brace to the tank bottom was overlapped and thus created a serious stress raiser. Weld repair and re-inspection of the tank were recommended prior to activation.

In November and December of 1963, EAS performed a cursory inspection of certain areas of the tank. No evidence of the VPI-220 was present. Several puddles of water were present on the tank bottom. There was also a heavy accumulation of corrosion products. Pits up to 0.075 inch deep were present beneath these deposits. The corrosion was attributed to rainwater leakage through risers that were not sealed. Corrosion of the sidewalls was observed to be much less than that on the bottom. As a result of these observations the following recommendations were made. 1) Remove excess water and rust scale from the tank bottom. 2) The tank bottom and walls up to approximately 8 feet high should be thoroughly inspected. 3) Repair as necessary areas where tank wall thickness has been decreased due to welding, cutting, grinding, etc. 4) Apply an additional coating of the VPI-220. 5) Seal risers so that they are leaktight. Of these recommendations, only documentation referring to the application of the additional coating of VPI-220 was located.

\subsection{In-Service Inspections of Type I and II Tanks and Tank 15}

Leakage of radioactive waste is detected by either a conductivity probe or visual inspection of the annular space between the primary and the secondary walls. However, because the amount of leakage is frequently small, the waste frequently dries and forms deposits on the wall before it reaches the conductivity probe at the bottom of the annulus pan. Therefore, routine periodic visual inspections have proven to be the most effective means for detecting leaksites. 
During a visual inspection of Tank 15 in 1972 two leaksites were discovered below one of the four risers providing access to the annulus near the bottom circumferential weld about 2.5 feet above the tank bottom [13]. Twelve additional risers were installed, increasing the observable portion of the primary steel wall from $25 \%$ to $96 \%$.

Inspections in 1973, via the additional risers, revealed eleven other leaksites. Figure 12 is a map of the primary tank wall showing the location of the leaksites.

Since 1992 three new cracks have been identified in Tank 15. The most serious case was found beneath riser 207 near the middle girth weld and is shown in Figure 13. This crack was discovered in 1994 and verified during non-destructive evaluation in 1998 to be a through-wall crack. There are several unique features of this crack compared to cracks that have appeared in this tank and others. First, the crack follows a curved path. Previous cracks were perpendicular to the weld [14] and were associated with the weld heat affected zone. Secondly, the crack is estimated to be 12-15 inches long. Previously the longest measured crack was six inches [14]. Finally, the waste level was five feet below the crack when the crack finally penetrated through the primary wall. This crack will be investigated from two aspects: a) what was the mechanism for crack propagation and is it unique to Tank 15 ? b) is the crack length greater than the critical flaw size for instability? Both issues have significant impact on the safe operation of the tank.

In addition to visual inspections ultrasonic thickness (UT) measurements of the primary wall have been performed periodically for all tanks[1]. The tests are performed on a vertical strip section of the primary. An analog instrument was used in 1967-69 to measure the thickness of selected double-wall tanks. In 1972, a more precise instrument was placed in service. Approximately 24,000 measurements were made with this instrument over a 14 year period (1972-85) on all of the tanks. The results of the tests indicated that no wall thinning has occurred. Figure 14 shows an example of the results of UT measurements in Tank 15. The wall thickness was greater than the nominal value at all points along the vertical strip. The last UT measurement was taken in 1984 nearly two years after the last operations (i.e., sludge removal) were performed in this tank.

\subsection{In-Service Inspections for the Type I and II Waste Tank Life Management Program}

The following sections describe the scope of the proposed waste tank inspection program. Other projects under the Life Management Program for Type I and II High Level Waste Tanks, such as the fracture mechanics assessment program, may also impact the scope of tank inspections.

The extent of the initial examination will focus on the characterization (size, location, etc.) of flaws reported by ongoing visual surveillance. For comparison purposes, a percentage of the welds that have shown no visual indications of cracks will also be surveyed. The actual percentage will be specified in a NDE scan plan that will be approved prior to the examination. The extent of examination is limited by the capability for mounting the crawler at precise locations on the primary tank wall, upon the robotic 
crawler reach, and any limitations to crawler movement. The crawler selected for these inspections must meet the following criteria: a) be able to negotiate through the 5 inch annulus riser access port, $b$ ) be able to manipulate the ultrasonic transducer probe to a position normal to a flaw's orientation, and c) be able to be mounted safely on the riser port without obstructing tank top access. These features will be addressed in the procurement specifications and during crawler performance demonstrations.

Subsequent periodic inspections may be instituted to monitor for flaw growth and emerging material aging conditions characterized during the initial inspections. The extent of these subsequent inspections will focus on high stress and other high risk locations identified by the Life Management Program.

The inspection frequency will depend on the flaw characterization during the initial inspection and knowledge of the crack growth rate. The flaw evaluation will define a critical crack length and allowable crack length. Provided the measured crack lengths are less than the allowable length, the initial crack length and the crack growth rate model will be utilized to determine the appropriate inspection interval. Selected known flaws will be re-examined at that time for growth. Depending upon the measured growth, the crack growth rate model may be adjusted and the inspection frequency adjusted accordingly. Partial through-wall flaws detected during inspection shall also be reexamined at frequencies determined during the flaw evaluation and analysis process.

Ultrasonic examinations shall be conducted in accordance with WSRC D2 Procedure Manual, Procedure NDEP 7.11, "Automated Ultrasonic Examination of Welded Ferritic Components" (U). Flaw sizing shall be performed in accordance with Procedure NDEP 7.10, "Automated Ultrasonic Planar Flaw Sizing" (U). Supplemental methods and techniques may be used to investigate and characterize flaws.

NDE Examiner qualification requirements are described in the procedures mentioned above for each method. Minimum NDE Personnel qualification requirements are defined in WSRC D2, NDEP 2.1 "Qualification and Certification of NDE Personnel". HLW may specify supplemental qualification or performance testing requirements for detection and sizing of certain damage mechanisms, as applicable.

NDE inspection records shall comply with the applicable Quality Assurance and NDE procedure requirements. Records of Performance demonstration tests for new equipment shall be documented by letter and distributed to the HLW Life Management Program Committee.

Any equipment such as robotic crawlers, scanners, etc. that are purchased or adapted to HLW Tank inspections shall be functionally tested to verify that they can perform their intended function under field conditions. The functional test shall verify the installation or mounting process, the ability to place or couple the device to the tank wall, the NDE sensor positioning for optimum probe motion for characterizing the flaw of interest, ultrasonic coupling function, and compliance with other crawler performance parameters 
such as drift, slippage, surface condition compatibility, speed uniformity, etc. Other performance parameters may be specified in the purchase order.

\subsection{Materials Property Database for Waste Tank Material}

The carbon steel material for both Type I and II tanks was formed per specification ASTM A285-50T, Grade B firebox quality (A285). The nominal composition and mechanical properties are shown in Table 4 [15]. The material was melted in an openhearth furnace, semi-killed and then hot rolled into plate. The rimmed process was not utilized. The material was suitable for submerged arc welding. . A carbon content of 0.22 wt. \% was allowed for plates that were greater than 0.75 inch thick, but less than or equal to 2 inch thick.

Table 4. ASTM Requirements for Chemical Composition and Tensile Properties for A285-50T, Grade B Firebox Quality.

\begin{tabular}{|l|c|c|c|c|c|c|c|}
\hline & \multicolumn{4}{|c|}{ Composition } & \multicolumn{3}{c|}{ Mechanical Properties Ranges } \\
\hline & C & Mn & P & S & $\begin{array}{c}\text { Tensile } \\
(\mathrm{ksi})\end{array}$ & $\begin{array}{c}\text { Yield } \\
(\mathrm{ksi})\end{array}$ & $\begin{array}{c}\text { \% Elong. } \\
\left(8^{\prime \prime}\right)\end{array}$ \\
\hline $\begin{array}{l}\text { For plates } \leq \\
\begin{array}{l}0.75^{\prime \prime} \text { in } \\
\text { thickness }\end{array}\end{array}$ & 0.2 & 0.8 & 0.035 & 0.04 & $50-60$ & 27 & 27 \\
\hline
\end{tabular}

Compositions are max. wt. \% and yield and elongation properties are min. values.

\subsection{Type I Tank Material Composition and Mechanical Properties}

U. S. Steel Corporation supplied essentially all of the material used in the tanks. A very small amount of material was supplied by Inland Steel [16]. The heat numbers for several of the plates utilized in the construction and the location in the tanks are shown in Table 5. The compositions and mechanical properties of the heats were gathered from mill test reports and they are shown in Table 6 . In all cases the heats met the requirements of being A285 carbon steel. One heat of material (344865) actually meets the requirements for ASTM A285, Grade C carbon steel. It is believed that the mechanical property tests were performed at ambient temperature.

\subsection{Type II Tank Material Composition and Mechanical Properties}

The material used to construct the tanks was supplied by Bethlehem Steel [17]. Table 7 lists the Graver purchase order numbers and from Bethlehem by tank location. The mill test report data on composition and tensile properties for all heats except one are shown in Table 8. In all cases the heats of material met the requirements for A285, Grade B material. In general, the material used for the tanks was lower in carbon than the material utilized for the Type I tanks ( 0.08 to $0.1 \mathrm{wt} . \%$ vs. 0.11 to $0.17 \mathrm{wt} . \%)$. In general, the strength of the material increases with carbon content, while the toughness of the material decreases. The lower carbon content material is also generally easier to weld. It is believed that the mechanical property tests were performed at ambient temperature. 
Table 5. Locations of Steel Plates in Type I Tanks for which the Chemical Composition and Mechanical Properties are Known.

\begin{tabular}{|c|c|c|}
\hline Tank\# & Location in Tank & Heat Numbers \\
\hline 1,2 & Roof & $\begin{array}{l}725217,824830 \\
844702\end{array}$ \\
\hline 2 & Roof Knuckles & $\begin{array}{l}315016,275090 \\
334965,364947 \\
344864\end{array}$ \\
\hline 3,4 & Roof & $\begin{array}{l}725217,824830, \\
844702\end{array}$ \\
\hline 3 & Roof Knuckles & $\begin{array}{l}275090,364947 \\
344864\end{array}$ \\
\hline 4 & Roof Knuckles & $\begin{array}{l}275090,334965 \\
364947,344864\end{array}$ \\
\hline $9,10,11$ & Pan Knuckles & 355086,344865 \\
\hline $9,10,11,12$ & Tank Bottom Plates & 775166 \\
\hline $9,10,11,12$ & Pan Bottom Plates & $\begin{array}{l}544979,355086, \\
725217,344865, \\
775166\end{array}$ \\
\hline 12 & Roof Knuckles & 275090 \\
\hline
\end{tabular}

Table 6. Composition and Mechanical Properties of Material Utilized in Type I Tanks.

\begin{tabular}{l|c|c|c|c|l|l|l}
\hline $\begin{array}{l}\text { U. S. Steel } \\
\text { Heat } \\
\text { Numbers }\end{array}$ & \multicolumn{4}{|c|}{ Composition } & \multicolumn{2}{c}{ Mechanical Property Ranges } \\
\cline { 2 - 7 } & $\mathrm{C}$ & Mn & $\mathrm{P}$ & $\mathrm{S}$ & $\begin{array}{l}\text { Tensile } \\
(\mathrm{ksi})\end{array}$ & $\begin{array}{l}\text { Yield } \\
(\mathrm{ksi})\end{array}$ & Elong. \\
\hline 275090 & 0.15 & 0.49 & 0.007 & 0.030 & $55.8-57.5$ & $31.1-33.9$ & $30.0-35.0$ \\
315016 & 0.17 & 0.47 & 0.008 & 0.032 & $56.5-57.5$ & 31.7 & 31.2 \\
334965 & 0.14 & 0.50 & 0.015 & 0.034 & $57.7-58.7$ & 31.1 & 33.2 \\
344864 & 0.12 & 0.53 & 0.013 & 0.030 & $54.0-54.2$ & 30.1 & 34.7 \\
344865 & 0.20 & 0.52 & 0.015 & 0.035 & $62.1-63.4$ & $35.9-36.7$ & $29.5-31.2$ \\
355086 & 0.14 & 0.49 & 0.008 & 0.026 & $55.6-56.9$ & $29.6-31.7$ & $29.5-35.0$ \\
364947 & 0.13 & 0.48 & 0.008 & 0.035 & $51.0-55.2$ & $28.5-29.0$ & $34.0-35.2$ \\
544979 & 0.12 & 0.39 & 0.010 & 0.025 & $53.0-55.8$ & 31.5 & 33.5 \\
725217 & 0.12 & 0.53 & 0.009 & 0.027 & $54.6-58.0$ & $33.8-41.9$ & $30.0-32.5$ \\
775166 & 0.12 & 0.53 & 0.009 & 0.032 & $53.4-57.2$ & $33.2-37.2$ & $31.0-34.0$ \\
824830 & 0.11 & 0.45 & 0.008 & 0.037 & $51.5-56.3$ & $30.6-33.9$ & $32.5-34.5$ \\
844702 & 0.15 & 0.52 & 0.009 & 0.030 & $58.6-59.0$ & 36.6 & 31.0 \\
\hline
\end{tabular}


Table 7. Locations of Steel Plates in Type I Tanks for which the Chemical Composition and Mechanical Properties are Known.

\begin{tabular}{lcc} 
& \multicolumn{2}{c}{$\begin{array}{c}\text { Graver Purchase Order No. on Bethlehem Steel Co. for } \\
\text { Material in Tanks 13 Through 16 }\end{array}$} \\
\cline { 2 - 3 } Location in Tank & \multicolumn{2}{c}{ S. R. S. Tank No. } \\
& 13 and 14 & 15 and 16 \\
\hline Bottom Knuckles & $7120 \times 7$ & $7120 \times 8$ \\
Bottom Rectangles & $7120 \times 8$ & $7120 \times 9$ \\
Lower Shell Rings & $7120 \times 8$ & $7120 \times 9$ \\
Upper Shell Rings & $7120 \times 11$ & $7120 \times 13$ \\
Top Knuckles & $7120 \times 11$ & $7120 \times 13$ \\
Roof & $7120 \times 12$ & \\
\hline
\end{tabular}

\subsection{Type IV Tank Material Composition and Mechanical Properties}

The tank liner for the Type IV tanks in F-Area (Tanks 17-20) was also constructed of A285 carbon steel. U. S. Steel manufactured the plate material in accordance with ASTM A285-54T specification [18]. This specification is the same as ASTM A285-50T. It was not possible to identify a specific heat of steel with a specific tank. The mill test report data for the material composition and mechanical properties for several heats of material are shown in Table 9. The compositions and mechanical properties were very similar to that for the Type I tanks.

Table 8. Composition and Mechanical Properties of Material Utilized in Type II Tanks.

\begin{tabular}{|c|c|c|c|c|c|c|c|c|}
\hline \multirow[b]{2}{*}{$\begin{array}{l}\text { Graver } \\
\text { P.O.\# }\end{array}$} & \multicolumn{2}{|l|}{ Bethlehem } & \multicolumn{3}{|c|}{ Composition } & \multicolumn{3}{|c|}{ Mechanical Property Ranges } \\
\hline & $\begin{array}{l}\text { Heat } \\
\text { Numbers }\end{array}$ & $\mathrm{C}$ & $\overline{\mathrm{Mn}}$ & $\mathrm{P}$ & $S$ & $\begin{array}{l}\text { Tensile } \\
\text { (ksi) }\end{array}$ & $\begin{array}{l}\text { Yield } \\
\text { (ksi) }\end{array}$ & \%Elong. (8") \\
\hline \multirow[t]{2}{*}{$7120 \times 7$} & $69 G 431$ & 0.08 & 0.45 & 0.01 & 0.021 & $51.5-55.1$ & $30.1-33.2$ & $28.0-37.0$ \\
\hline & $68 \mathrm{G} 418$ & 0.10 & 0.37 & 0.013 & 0.02 & $55.2-55.4$ & $33.5-33.9$ & 33.0 \\
\hline \multirow[t]{3}{*}{$7120 \times 8$} & $86 G 418$ & 0.09 & 0.45 & 0.012 & 0.022 & $54.5-56.8$ & $32.9-34.8$ & $30.0-34.0$ \\
\hline & $68 G 548$ & 0.12 & 0.53 & 0.013 & 0.027 & $56.3-56.8$ & 33.3-33.5 & $28.0-30.0$ \\
\hline & $79 \mathrm{G} 425$ & 0.08 & 0.44 & 0.01 & 0.03 & $53.7-60.0$ & $30.0-37.6$ & $28.0-34.0$ \\
\hline \multirow[t]{3}{*}{$7120 \times 9$} & $84 \mathrm{G} 468$ & 0.09 & 0.44 & 0.009 & 0.029 & $54.8-56.7$ & $30.7-33.8$ & $28.0-32.0$ \\
\hline & $79 \mathrm{G} 425$ & 0.08 & 0.44 & 0.01 & 0.03 & $55.0-57.0$ & $33.2-33.6$ & $30.0-33.0$ \\
\hline & 69G134 & \multicolumn{4}{|c|}{ Chemical composition not given } & 55.6 & $33.6-33.9$ & $31.0-33.0$ \\
\hline $7120 \times 11$ & \multicolumn{8}{|c|}{ No mill test reports on this order available } \\
\hline \multirow[t]{2}{*}{$7120 \times 12$} & $87 \mathrm{G} 512$ & 0.09 & 0.4 & 0.01 & 0.03 & $55.8-57.7$ & $34.6-38.2$ & $29.0-33.0$ \\
\hline & $67 \mathrm{G575}$ & 0.16 & 0.58 & 0.01 & 0.025 & 59.0 & 31.7 & 31.0 \\
\hline \multirow[t]{3}{*}{$7120 \times 13$} & $87 G 512$ & 0.09 & 0.6 & 0.01 & 0.03 & $54.4-57.7$ & $30.5-38.7$ & $29.0-35.0$ \\
\hline & $84 \mathrm{G} 468$ & 0.09 & 0.44 & 0.009 & 0.029 & $55.4-55.6$ & $35.7-36.5$ & 33.0 \\
\hline & $79 G 451$ & 0.11 & 0.46 & 0.01 & 0.033 & $58.3-59.8$ & $31.6-33.6$ & $25.0-28.0$ \\
\hline
\end{tabular}


Table 9. Composition and Mechanical Properties of Material Utilized in Type IV Tanks.

\begin{tabular}{|l|c|c|c|c|l|l|l|}
\hline U. S. Steel & \multicolumn{4}{|c|}{ Composition } & \multicolumn{3}{|c|}{ Mechanical Property Ranges } \\
\hline Heat Number & $\mathrm{C}$ & $\mathrm{Mn}$ & $\mathrm{P}$ & $\mathrm{S}$ & $\begin{array}{l}\text { Tensile } \\
(\mathrm{ksi})\end{array}$ & $\begin{array}{l}\text { Yield } \\
(\mathrm{ksi})\end{array}$ & E Elong. \\
\hline 65U421 & 0.13 & 0.48 & 0.011 & 0.029 & $55.5-58.0$ & $39.3-41.1$ & $27.5-35.0$ \\
\hline $66 \mathrm{U} 443$ & 0.12 & 0.50 & 0.012 & 0.038 & $55.1-58.7$ & $34.7-46.1$ & $28.7-35.0$ \\
\hline $74 \mathrm{U} 462$ & 0.12 & 0.53 & 0.009 & 0.03 & $55.4-57.6$ & $33.1-35.5$ & $24.2-35.0$ \\
\hline $65 \mathrm{U} 427$ & 0.12 & 0.45 & 0.013 & 0.022 & $54.5-59.3$ & $37.6-39.1$ & $28.7-33.5$ \\
\hline $75 \mathrm{U} 466$ & 0.11 & 0.42 & 0.016 & 0.035 & $55.2-56.3$ & $38.7-42.3$ & $32.5-36.5$ \\
\hline $61 \mathrm{U} 478$ & 0.13 & 0.52 & 0.014 & 0.025 & $56.1-57.4$ & $38.4-40.6$ & $33.2-35.2$ \\
\hline $68 \mathrm{U} 530$ & 0.13 & 0.51 & 0.013 & 0.033 & $57.6-59.1$ & $42.3-44.4$ & $29.0-35.0$ \\
\hline
\end{tabular}

\subsection{Reactor Cooling Water System Material Composition and Mechanical Properties}

The piping for the reactor cooling water steel was also constructed of A285 Grade B. The piping was 42 inches in diameter and had 0.5 inch wall thickness. After 15 to 20 years of service four pieces of pipe and two weld regions were machined from the pipe in 1980 [19]. The composition of the pipe and weld material shown in Table 10 is very similar to that for the tanks.

The materials were machined into tensile bars and tested at $40^{\circ} \mathrm{F}$. Both static and dynamic testing was performed to account for normal and seismic loads. The loading rate during the static tests was approximately $1 \mathrm{ksi} / \mathrm{s}$, while for the dynamic tests the loading rate was $3000 \mathrm{ksi} / \mathrm{s}$. The mechanical properties obtained from the static tests are shown in Table 11. The difference in the tensile properties for the piping versus the tanks due to the lower test temperature is probably insignificant (i.e., $40^{\circ} \mathrm{F}$ vs. $70^{\circ} \mathrm{F}$ or higher). It also appears that the degradation in pipe mechanical properties due to service was minimal. The tensile specimens for the weld material were machined so that the gage section contained base, heat-affected zone, and weld metal. All failures of these specimens occurred in the base metal. Thus, neither the weld metal nor the heat-affected zone is the weak link in the weld area. The mechanical properties for the dynamic tests are shown in Table 12. The lower yield stress from the dynamic tests was approximately $15 \mathrm{ksi}$ greater than that for the static test. This increase is in agreement with the increase estimated from ASTME 399 Annex 7. In addition, the upper yield was in many cases greater than the point normally associated with ultimate strength. The mechanism governing this phenomenon was unknown. 
Table 10. Composition of Material Utilized in Reactor Cooling Water System.

\begin{tabular}{llcccccc}
\hline Material & Spec. ID & C & Mn & P & S & Cu & Si \\
& & & & & & & \\
\hline A285 Pipe & P5 & 0.14 & 0.56 & 0.006 & 0.029 & 0.045 & 0.09 \\
A285 Pipe & P6 & 0.12 & 0.56 & 0.007 & 0.020 & 0.096 & 0.12 \\
A285 Pipe & P7 & 0.12 & 0.54 & 0.007 & 0.027 & 0.17 & 0.11 \\
A285 Pipe & P8 & 0.10 & 0.58 & 0.006 & 0.027 & 0.10 & 0.1 \\
A285 & CW11 & 0.09 & 0.56 & 0.008 & 0.015 & 0.095 & 0.14 \\
Weld & & & & & & & \\
A285 & CW12 & 0.09 & 0.54 & 0.008 & 0.017 & 0.1 & 0.13 \\
Weld & & & & & & & \\
\hline
\end{tabular}

Table 11. Static Test Mechanical Properties of Material Utilized in the Reactor Cooling Water System.

\begin{tabular}{|c|c|c|c|c|c|c|c|}
\hline \multirow[t]{2}{*}{ Material } & \multirow[t]{2}{*}{ Spec. ID } & \multicolumn{3}{|c|}{ Yield Stress } & \multirow{2}{*}{$\begin{array}{l}\text { Ultimate } \\
\text { Stress } \\
\text { (ksi) }\end{array}$} & \multirow{2}{*}{$\begin{array}{l}\text { Elonga- } \\
\text { tion } \\
\text { (\%) }\end{array}$} & \multirow{2}{*}{$\begin{array}{l}\text { Reduc- } \\
\text { tion } \\
(\%)\end{array}$} \\
\hline & & $\begin{array}{l}\text { Upper } \\
\text { (ksi) }\end{array}$ & $\begin{array}{l}\text { Lower } \\
\text { (ksi) }\end{array}$ & $\begin{array}{l}0.2 \% \\
\text { (ksi) }\end{array}$ & & & \\
\hline \multicolumn{8}{|c|}{ Static Tests } \\
\hline A285 Pipe & P5-2 & 43.0 & 36.6 & 37.1 & 58.0 & 39.2 & 70.0 \\
\hline A285 Pipe & P6-2 & 38.3 & 34.7 & 35.6 & 57.8 & 39.6 & 70.4 \\
\hline A285 Pipe & P7-2 & 42.8 & 35.6 & 35.9 & 59.6 & 37.8 & 69.1 \\
\hline A285 Pipe & P8-2 & 43.4 & 36.8 & 37.5 & 57.8 & 39.4 & 68.2 \\
\hline A285 Weld & CW11-2 & 47.9 & 43.8 & 45.0 & 62.8 & 35.5 & 66.8 \\
\hline A285 Weld & CW12-2 & 49.4 & 46.5 & 47.2 & 63.5 & 23.0 & 66.8 \\
\hline
\end{tabular}

Table 12. Dynamic Test Mechanical Properties of Material Utilized in the Reactor Cooling Water System.

\begin{tabular}{|c|c|c|c|c|c|c|}
\hline \multirow{2}{*}{ Material } & \multirow[t]{2}{*}{ Spec. ID } & \multicolumn{2}{|c|}{ Yield Stress } & \multirow{2}{*}{$\begin{array}{l}\text { Ultimate } \\
\text { Stress } \\
\text { (ksi) }\end{array}$} & \multirow{2}{*}{$\begin{array}{l}\text { Elonga- } \\
\text { tion } \\
(\%)\end{array}$} & \multirow{2}{*}{$\begin{array}{l}\text { Reduc- } \\
\text { tion } \\
(\%)\end{array}$} \\
\hline & & $\begin{array}{l}\text { Upper } \\
\text { (ksi) }\end{array}$ & $\begin{array}{l}\text { Lower } \\
\text { (ksi) }\end{array}$ & & & \\
\hline \multicolumn{7}{|c|}{ Dynamic Tests } \\
\hline A285 Pipe & P5-1 & 74.8 & 51.0 & 66.6 & 30.9 & 64.5 \\
\hline A285 Pipe & P6-1 & 70.1 & 46.9 & 63.9 & 32.5 & 66.4 \\
\hline A285 Pipe & P7-1 & 66.1 & 51.8 & 66.2 & $=$ & 66.3 \\
\hline A285 Pipe & P8-1 & 68.9 & 50.1 & 63.8 & 32.8 & 67.3 \\
\hline A285 Weld & CW11-1 & 71.8 & 58.2 & 69.3 & -. & 71.3 \\
\hline
\end{tabular}

\subsection{Fracture Properties of A285 Carbon Steel}

No fracture properties of the carbon steel were required at the time the waste tanks were constructed. In the 1970's the low fracture toughness properties of the A285 material became a concern. Charpy V-Notch (CVN) testing was performed on archival tank material. The results of these tests were summarized in a previous document [20]. The primary conclusion from this analysis was that the steel at temperatures greater than $70^{\circ} \mathrm{F}$ 
will exhibit upper transition to upper shelf behavior. Under these conditions, the initial growth of structural flaws would be stable extension by ductile tearing if the mechanical loads produce sufficient stresses. Given that the Technical Safety Requirements (TSR) [21] require that the tank wall temperature be greater than $70^{\circ} \mathrm{F}$, fracture analyses based on ductile failure or on elastic-plastic tearing instability criteria are applicable to the waste tanks.

Testing was also performed on archived reactor cooling water piping in 1983 [19]. The CVN tests were at two different orientations, the L-C (flaw perpendicular to the rolling direction) and C-L (flaw parallel to the rolling direction). The CVN tests were in good agreement with the tests that were performed on the waste tank material. The Ductile to Brittle Transition Temperature (DBTT) in each case was about $45^{\circ} \mathrm{F}$. The orientation had a significant effect on the upper shelf energy. The upper shelf energy for specimens in the L-C orientation was 3-4 times greater than for the specimens tested in the C-L orientation.

In addition to CVN testing, static and dynamic testing of $0.4 \mathrm{C}(\mathrm{T})$ specimens was performed. The tests were conducted at $40 \mathrm{~F}$ and with the specimens oriented in the $\mathrm{L}-\mathrm{C}$ orientation (i.e., the orientation with the highest degree of toughness). The results of the $\mathrm{C}(\mathrm{T})$ tests provided fracture properties in the form of J-R curves. $\mathrm{J}$ is the energy made available at the crack tip per unit crack extension, $\Delta$ a. The $J$ value that was calculated was a modified $\mathrm{J}\left(\mathrm{J}_{\mathrm{m}}\right)$, where $\mathrm{Jm}$ is the deformation theory $\mathrm{J}\left(\mathrm{J}_{\mathrm{D}}\right)$ adjusted by a term that accounted for the elastic plastic failure. For small crack extensions on the order of $1 \mathrm{~mm}$ $J_{m}$ equals $J_{D}[19]$.

The $\mathrm{J}_{\mathrm{m}} \mathrm{vs.} \Delta \mathrm{a}$, curves under static loading conditions are shown in Figure 15. The data was fit to a power law equation of the form, $J=C(\Delta a)^{n}$ where $C$ and $n$ are constants. The values for $\mathrm{C}$ and $\mathrm{n}$ are shown in Table 13. $\mathrm{J}_{\mathrm{Ic}}$ is the energy at the onset of crack initiation. This value was calculated from the power law equation at a fixed crack extension of $0.2 \mathrm{~mm}$. This fixed crack extension was chosen based on past experience and approximates the maximum blunting extension attainable with low strength structural steels. From this value, the elastic initiation fracture toughness $\mathrm{K}_{\mathrm{Jc}}$ may be calculated from the following equation:

$$
\mathrm{K}_{\mathrm{Ic}}=\left[\mathrm{EJ}_{\mathrm{Id}}\left(1-\mathrm{v}^{2}\right)\right]^{0.5}
$$

where $v=0.3$ and $E=3 \times 10^{7}$ psi. The values for $\mathrm{K}_{\mathrm{Jc}}$ are shown in Table 14. The average toughness for the pipe material was $205 \mathrm{ksi} V_{\text {in }}$ with a standard deviation of $42 \mathrm{ksi} V_{\mathrm{in}}$. while for the weld material the average toughness was $148.5 \mathrm{ksi}$ in and the standard deviation was $7.8 \mathrm{ksi} V \mathrm{in}$. The levels of toughness were considered quite high and would preclude fracture under linear elastic conditions for the relatively thin pipe walls. Ductile failure was characterized by slow stable crack extension that requires additional energy input to continue crack extension. Cleavage failure is characterized by sudden unstable crack extension and propagation sustained by energy stored within the test specimen. Ductile/cleavage failure indicated cases where ductile crack extension preceded a 
cleavage fracture. All failures in the piping material were ductile, while one of the weld materials was ductile/cleavage failure.

Table 13. Exponent and Coefficient for Power Law Calculation of J from the Static Tests for the A285 piping and weld material.

\begin{tabular}{|c|c|c|}
\hline Specimen Number & $\mathrm{C}\left(\right.$ Newton $\left./(\mathrm{mm})^{\mathrm{n}+1}\right)$ & $\underline{\mathrm{n}}$ \\
\hline P5-2 & 328.1 & $0 . \overline{6578}$ \\
\hline P6-2 & 704.2 & 0.6688 \\
\hline P7-2 & 601.2 & 0.571 \\
\hline P8-2 & 951.5 & 0.6716 \\
\hline CW11-2 & 408 & 0.7346 \\
\hline CW12-2 & 372.8 & 0.7668 \\
\hline
\end{tabular}

Table 14. Static Fracture Toughness Data

$\begin{array}{cccc}\begin{array}{c}\text { Specimen } \\ \text { Number }\end{array} & \begin{array}{c}\mathrm{J}_{\mathrm{Ic}} \\ \left(\mathrm{in}-\mathrm{lb}_{\mathrm{in}}{ }^{2}\right)\end{array} & \begin{array}{c}\mathrm{K}_{\mathrm{Jc}} \\ (\mathrm{ksi} \sqrt{\mathrm{kin})}\end{array} & \begin{array}{c}\text { Failure } \\ \text { Type }\end{array} \\ \text { P5-2 } & 650 & 146 & \text { Ductile } \\ \text { P6-2 } & 1370 & 213 & \text { Ductile } \\ \text { P7-2 } & 1369 & 212 & \text { Ductile } \\ \text { P8-2 } & 1844 & 247 & \text { Ductile } \\ \text { CW11-2 } & 714 & 154 & \text { Ductile/Cleavage } \\ \text { CW12-2 } & 620 & 143 & \text { Ductile }\end{array}$

Dynamic fracture tests were also performed in accordance with the procedures detailed in ASTM Standard E399, Annex 7. This procedure was designed to apply to conditions where loading rates exceed those for conventional static testing. However, the materials that were tested demonstrated significant plastic deformation prior to specimen failure, thus failing to meet the Annex 7 validity requirements. Since the dynamic testing results did not meet the criteria for either linear elastic or fully plastic failure, $J_{\text {Ic }}$ was taken to be approximately at the first load peak on the load vs. deflection plot. To quantify $J_{I c}$, the energy input to the test specimen (A) was determined directly form the load vs. specimen front face deflection plots using a planimeter. $J_{\mathrm{Ic}}$ was calculated from the following equation:

$$
\mathrm{J}_{\mathrm{lc}}=2 \mathrm{~A} / \mathrm{bB}
$$

where $b$ is the remaining unbroken ligament and $B$ is the specimen thickness. $K_{\mathrm{Jc}}$ was calculated by the same equation shown above. These values are shown in Table 15. The average toughness for the pipe material was $70.6 \mathrm{ksi}$ in with a standard deviation of 10 $\mathrm{ksi} V_{\mathrm{in}}$, while the weld material had an average toughness of $92 \mathrm{ksi}$ in with a standard deviation of $4 \mathrm{ksi} V_{\mathrm{in}}$. These values represent a $65 \%$ decrease in toughness for the piping and a $38 \%$ decrease in toughess for the weld material when compared with the static test 
results. The dynamic results suggest that the weld material is tougher whereas the static tests suggest the opposite. In addition the data indicate that the weld metal is somewhat less sensitive to dynamic loading than the piping material. Care must be taken however, in making to broad of a generalization as there is significant scatter in the plate data and there are only two data points for the weld material.

Table 15. Dynamic Fracture Toughness Data.

$\begin{array}{cccc}\begin{array}{c}\text { Specimen } \\ \text { Number }\end{array} & \begin{array}{c}\underline{\mathrm{J}_{\mathrm{Ic}}} \\ \left(\mathrm{in}-\mathrm{lb}_{\mathrm{in}}{ }^{2}\right)\end{array} & \begin{array}{c}\underline{\mathrm{K}_{\mathrm{Ic}}} \\ (\mathrm{ksi} \sqrt{\mathrm{in}})\end{array} & \begin{array}{c}\text { Failure } \\ \text { Type }\end{array} \\ \text { P5-1 } & 191 & 79 & \text { Ductile } \\ \text { P6-1 } & 132 & 66 & \text { Ductile } \\ \text { P6-3 } & 178 & 77 & \text { Ductile } \\ \text { P6-4 } & 121 & 63 & \text { Ductile } \\ \text { P6-5 } & 123 & 64 & \text { Ductile } \\ \text { P6-6 } & 110 & 60 & \text { Ductile } \\ \text { P6-7 } & 132 & 66 & \text { Ductile/Cleavage } \\ \text { P6-8 } & 124 & 64 & \text { Ductile/Cleavage } \\ \text { P7-1 } & 244 & 90 & \text { Cleavage } \\ \text { P8-1 } & 179 & 77 & \text { Ductile } \\ \text { CW11-1 } & 242 & 89 & \text { Ductile/Cleavage } \\ \text { CW12-1 } & 273 & 95 & \text { Ductile }\end{array}$

There are at least three areas where this material property database may be improved:

1. The database of elastic-plastic fracture toughness properties is applicable to conditions at $40^{\circ} \mathrm{F}$. Elastic-plastic fracture toughness data at temperatures greater than $70^{\circ} \mathrm{F}$ could be generated through testing archival or other A285 material.

2. The testing should consider aspects of constraint. The $\mathrm{J}_{\mathrm{A} 2}$ methodology allows for consideration of constraint effects [21].

3. The effects of service exposure on the material properties could be investigated.

Each of these would be performed in Phase 2 of the life extension program [2].

\subsection{Fracture Properties in a Waste Environment}

Failure of structural components exposed to corrosive environments may occur under stresses that are less than the yield stress of the material. The mechanism under these conditions is referred to as stress corrosion cracking (SCC). The SCC crack growth rate generally varies with the stress intensity parameter $\left(\mathrm{K}_{\mathrm{I}}\right)$ in the manner shown in Figure 16 [22]. In region $A$, crack growth is strongly related to stress intensity but drops very rapidly, nominally to zero. Extrapolation to zero crack growth provides the value $\mathrm{K}_{\mathrm{Iscc}}$ (Note: In experiments, crack growth rates less than $10^{-5} \mathrm{in} / \mathrm{hr}$ are considered to be negligible). $\mathrm{K}_{\mathrm{Iscc}}$ is the stress intensity factor above which SCC will initiate and grow for the specified condition (material, environment, exposure time, etc.) under predominantly plane strain conditions. This parameter is a material property for a given 
environment/material system. From a structural stability standpoint, it is preferable to demonstrate that existing or postulated defects produce values of the stress intensity factor that are less than $\mathbf{K}_{\mathrm{Iscc}}$.

In general, the higher the yield strength for a given material, the lower the $\mathrm{K}_{\mathrm{Iscc}}$ value in a given environment [23]. In general, $\mathrm{K}_{\mathrm{Iscc}}$ values for steels that have yield strength below $130 \mathrm{ksi}$ correspond to conditions involving substantial crack tip plasticity. Consequently, linear elastic fracture mechanics concepts cannot be used for quantitative analysis of SCC behavior. Furthermore, the apparent $\mathrm{K}_{\mathrm{Iscc}}$ values are suppressed to various degrees below the intrinsic $\mathrm{K}_{\mathrm{Iscc}}$ values in a manner similar to the suppression effect for fracture behavior. For these cases the most important parameter becomes the ratio of the apparent $\mathrm{K}_{\mathrm{Iscc}}$ to the stress intensity value at fracture obtained with an identical size specimen. This ratio is known as the relative index of stress corrosion cracking susceptibility. Ratios less than 0.8 indicate susceptibility to stress corrosion cracking.

There are several other variables that affect $\mathrm{K}_{\mathrm{Iscc}}$. These include specimen thickness, prior heat treatment of the specimen, and orientation of the specimen. Therefore, knowledge of the actual plate thickness, the material fabrication processes (cold-work, hot-forming, etc.), and the procedures for construction would be useful in determining the appropriate test data to apply to the fracture analysis.

Modified wedge opening load (WOL) specimens may be utilized to determine $\mathrm{K}_{\text {Iscc }}$. Tests were performed at SRS to determine the effect of the waste composition on crack growth in A285 material [24]. Material was machined into a 0.75 " thick WOL specimen with side grooves. The specimens were pre-cracked by fatigue and were initially loaded so that the crack opening displacement was equivalent to an apparent stress intensity of $45 \mathrm{ksi} \sqrt{ }$ in. Due to the large plasticity of the mild steel, the load required to achieve an actual stress intensity of $45 \mathrm{ksi}$ in could not be met.

The specimens were immersed in 5 molar $(M)$ sodium nitrate solutions that contained various amounts of sodium hydroxide $(0$ to $1.5 \mathrm{M})$ and sodium nitrite $(0$ to $3 \mathrm{M})$. The test temperature was $95^{\circ} \mathrm{C}$. For this type of specimen the stress intensity, $\mathrm{K}_{\mathrm{I}}$, a parameter that characterizes the state of stress in the crack tip region, decreases with crack length. Therefore, the threshold stress intensity, $K_{\text {Iscc }}$ (the minimum stress intensity for stress corrosion cracking under plane-strain conditions), is the $\mathrm{K}_{\mathrm{I}}$ value found when the crack ceases to grow. $\mathrm{K}_{\mathrm{Iscc}}$ was observed to be relatively independent of the bulk solution chemistry. This observation is evidence that the crack tip chemistry is independent of the bulk chemistry. The average $\mathrm{K}_{\mathrm{Iscc}}$ was $28.5 \mathrm{ksi}$ in.

However, should the threshold data reveal the potential for SCC in-service, it will be necessary to predict the crack extension based on crack growth rate data. Over region $B$ in Figure 16, cracks grow at a constant rate that is independent of stress intensity and is faster that the crack growth rate in a non-cracking environment. It is believed that the growth rate is related to the corrosion processes that are occurring at the crack tip. Crack length as a function of time was also measured during the WOL tests. The growth rate 
was also observed to be independent of the bulk solution chemistry. The average crack growth rate was 1.25 inches per year.

In region $\mathrm{C}$ of Figure 16 the stresses are very high, and the inter-atomic bonds break before any significant corrosion reactions can occur. The crack growth rate accelerates rapidly as the value for $K_{I}$ approaches $K_{I c}$ for the material.

\subsection{Operational History for Tank 15}

Much of the operational history of Tank 15 has been recorded as part of the series of tank histories prepared by the former Separations Technology Department. The Tank 15 history by Davis, Tharin, and Lohr provides a chronology of service events from 1959 to 1974[13]. Data on tank levels and temperatures are found in the high-level waste computerized database maintained by the Concentration, Storage, and Transfer Engineering Department, and in the following documents: waste management monthly data records [25], waste management technology monthly reports [26], waste management programs monthly reports [27], and waste management morning reports.

Tank 15 entered radioactive waste service in October 1960, when it received 369,000 gallons of waste transferred from Tank 16 (to lower the waste height in Tank 16 below numerous leak sites). Thereafter the principal service of Tank 15 was as a high-heat waste receiver from 1961 to 1972 . Tank 15 received primarily waste from the enriched uranium (HM) process; some low-heat and thorex process waste was received also. The tank was filled with fresh waste five times to near its allowed maximum height of $306 \mathrm{in}$. (about 1,060,000 gallons) in the 1961-72 period. Between fillings, sludge was allowed to settle and supernatant liquid was then transferred to Tank 13 to create space for the next fresh waste receipt. Thus sludge steadily accumulated to a volume of about 320,000 gallons in 1972, as shown in Figure 17. At that time total waste volume was 952,000 gallons. Evaporation of supernate in the years 1972-1978 reduced the total waste volume to 870,000 gallons. In 1978 supernate was again decanted from Tank 15 in two transfers to create space for the receipts of sludge slurry and rinse water from Tank 16. Two transfers from Tank 16 in 1979 and 1980 raised the Tank 15 sludge volume to between 370,000 and 390,000 gallons, and total waste volume to 800,000 gallons. The last major activity for Tank 15 was the suspension of the sludge with slurry pumps and the transfer of the sludge slurry to Tank 42 . This activity in early 1982 allowed some 100,000 gallons of slurry pump seal water to enter the tank (the peak in total volume in early 1982. In March 1982, two transfers of sludge slurry to Tank 42 totaling 727,000 gallons were completed. (This waste subsequently became the feed for the initial vitrification campaign in the Defense Waste Processing Facility.)

Since 1982 Tank 15 has been inactive. Total volume has declined as the supernate evaporated to no measurable liquid after 1989. Present volume is about 240,000 gallons. (The higher value in Figure 17 reflects the parking of the level indicator above the sludge height.) The present sludge level is apparently not constant but varies across the tank from about 71 inches to about 35 inches ( $R$. Ross, private communication). 
Figure 18 shows a graph of the sludge and supernate temperatures in Tank 15. The sludge temperature peaked in accordance with receipts of fresh waste, rising to the range 115 to $125^{\circ} \mathrm{C}$ from 1966 to 1972 and falling below $70^{\circ} \mathrm{C}$ thereafter. Sludge temperatures have varied from 20 to $65^{\circ} \mathrm{C}$ in recent years with seasonal rises and falls and with cooling coil usage. Supernate temperatures have varied between 25 and $70^{\circ} \mathrm{C}$.

Table 16 shows a history of the supernate chemistry in Tank 15 . The corrosive species is nitrate, while nitrite and hydroxide are corrosion inhibitors. The supernate concentration listed December 1972 is representative of the HM waste that was transferred from the canyon to this tank from 1960-72. A decrease in the concentrations was observed in 1979 due to the addition of slurried sludge from Tank 16. A year later this concentration increased to the previous values probably due to diffusion of the components from the heavy salt solution into the dilute layer. In September of 1980 another batch of slurried sludge was received from Tank 16. The sample that was taken is representative of the dilute phase. A year later, diffusion again resulted in an increase in the concentrations. In 1982, sludge from Tank 15 was slurried and sent to Tank 42 . This operation diluted the supernate. Since then there have been no operations in Tank 15. The sample taken in 1984 seems to give a spurious result. However, after 1984 the concentrations measured were relatively consistent with that which was present after the sludge removal operations. Since 1988, there has not been a sufficient amount of supernate in Tank 15 to sample.

Table 16. Results of Sampling for Supernate Chemistry

\begin{tabular}{|c|c|c|c|c|c|}
\hline Date & $\begin{array}{l}\text { Specific } \\
\text { Gravity }\end{array}$ & $\mathrm{pH}$ & $\begin{array}{l}\text { Nitrite } \\
\text { (M) }\end{array}$ & $\begin{array}{l}\text { Nitrate } \\
(\mathrm{M})\end{array}$ & $\begin{array}{l}\text { H y d roxide } \\
(\mathrm{M})\end{array}$ \\
\hline $03 / 07 / 88$ & 1.266 & 13.600 & 0.096 & 1.100 & 1.116 \\
\hline $12 / 01 / 87$ & 1.230 & 13.260 & 1.400 & 1.570 & 0.073 \\
\hline $09 / 06 / 85$ & 1.170 & 12.900 & 0.860 & 1.300 & 0.220 \\
\hline $12 / 11 / 84$ & 1.105 & 13.180 & 0.680 & 1.180 & 0.136 \\
\hline $09 / 20 / 84$ & 1.147 & 13.410 & 1.750 & 3.400 & 0.159 \\
\hline $03 / 03 / 82$ & 1.170 & & 0.580 & 1.440 & 0.510 \\
\hline $02 / 19 / 82$ & & & 0.650 & 1.680 & 0.860 \\
\hline $09 / 10 / 81$ & 1.240 & 12.400 & 0.600 & 2.100 & 0.800 \\
\hline $09 / 22 / 80$ & 1.060 & 13.400 & $<0.1$ & 0.200 & 0.400 \\
\hline $04 / 25 / 80$ & 1.260 & 11.200 & 0.800 & 4.100 & 1.200 \\
\hline $.03 / 03 / 79$ & & & 0.350 & 3.000 & 1.520 \\
\hline $12 / 19 / 72$ & 1.290 & & 1.100 & 3.600 & 1.000 \\
\hline
\end{tabular}

\subsection{Conclusions}

This document has collated a general database of information on the Type I and II waste tanks. The information included a description of the tank fabrication and construction procedures, the dimensions of the tank, details of pre-service and in-service inspections, 
the tank material properties, and the operational history of Tank 15. This information will provide a basis for further analyses such as defining requirements for further testing, determination of critical flaw size, and determination of corrosion mechanism. These analyses will lead to an assessment of the current condition of Tank 15 and the formulation of a life management program for the Type I and II tanks.

\subsection{Acknowledgements}

The authors acknowledge the assistance of C. D. Cowfer in preparing the section 4.3.

\subsection{References}

1. F. G. McNatt, "Annual Radioactive Waste Tank Inspection Program - 1997 (U)", WSRC-TR-98-0083, May 1998.

2. B. J. Wiersma and E. Nomm, "Life Management Program for Types I and II Waste Tanks", HLW-CSTE-98-D096, April 27, 1998.

3. "Rules for Construction of Unfired Pressure Vessels", Section VIII of the ASME Boiler Construction Code, 1949.

4. "Rules for Construction of Unfired Pressure Vessels", Section VIII of the ASME Boiler Construction Code, 1952.

5. BPF209167

6. Drawing W162672, Detail C.

7. F. T. Wyman to W. L. Poe, "Inspection of Empty Waste Tank 241-H-15", October $15,1959$.

8. W. L. Poe to J. H. Nuzum, "Repair of Waste Storage Tank, 241-H-15", March 18, 1960.

9. F. T. Wyman to A. E. Wible, "Inspection Results of Waste Storage Tank No. 4, 241F", April 11, 1961.

10. R. L. Hooker to A. J. Sauerborn, "Empty Waste Tank 6F Condition and Program", February 25, 1964.

11. J. H. Fuller to H. A. L. Fritze- R. E. Mauricette, Tank 6F inspection, October 7, 1953.

12. F. T. Wyman, 200-Area Metallurgical Report, February 15; 1961.

13. T. L. Davis, D. W. Tharin, and D. R. Lohr, "History of Waste Tank 15: 1959 , through 1974", DPSPU-77-11, June 1978.

14. B. J. Wiersma and R. L. Sindelar, "Reference Flaw Size for Types I and II Waste Tanks", WSRC-TR-94-041, January 1994.

15. "Tentative Specification for Low and Intermediate Tensile Strength Carbon Steel Plates of Flange and Firebox Qualities" ASTM A285-52a T, Issued May 1949, Revised, December 1949, September and December 1950, and February and September 1952.

16. W. C. Rion to E. A. Hein, "Survey of Steel Plate Compositions in Project 8980 Tanks", October 7, 1959.

17. W. C. Rion to E. A. Hein, "Survey of Steel Plate Composition in PWO-6010H Tanks", October 5, 1959. 
18. W. C. Rion to E. A. Hein, "Steel Tank Liner - Summary of Steel Compositions and Properties", April 8, 1964.

19. B. H. Menke, F. J. Loss, and J. R. Hawthorne, "Savannah River Nuclear Facility Piping Material Characterization", Materials Engineering Associates, MEA-2033, November 11, 1983.

20. R. L. Sindelar and B. J. Wiersma, "Fracture Characterization and Toughness of ASTM A285 Carbon Steel for Types I and II Waste Tanks", WSRC-TR-94-038, February 1994.

21. S. Yang, Y. J. Chao, and M. A. Sutton, "Higher Order Asymptotic Crack Tip Fields in a Power-Law Hardening Material", Engineering Fracture Mechanics, Vol. 45, No. 1 pp. $1-20$.

22. A. J. Sedricks, Stress Corrosion Cracking Test Methods, National Association of Corrosion Engineering, Houston, TX, 1990, p. 53.

23. S. T. Rolfe and J. M. Barsom, Fracture and Fatigue Control in Structures:

Applications of Fracture Mechanics, Prentice-Hall, Englewood Cliffs, NJ, 1977, pp. 292-311.

24. J. A. Donovan, "Factors Controlling Nitrate Cracking of Mild Steel", Proceedings of Conference on Environmental Degradation of Engineering Materials, Blacksburg, VA, October 1977.

25. Waste Management Monthly Data Record, WSRC-RP-92-78-1B, January, 1992. Later years the document was referred to as High Level Waste Engineering Monthly Data Record.

26. 'Waste Management Technology Monthly Report, WSRC-RP-92-78-1A, January, 1992. Later years the document was referred to as the High Level Waste Engineering Monthly Report.

27. Waste Management Operations and Surveillance Monthly Report, WER-WMF-920048, January, 1992. 


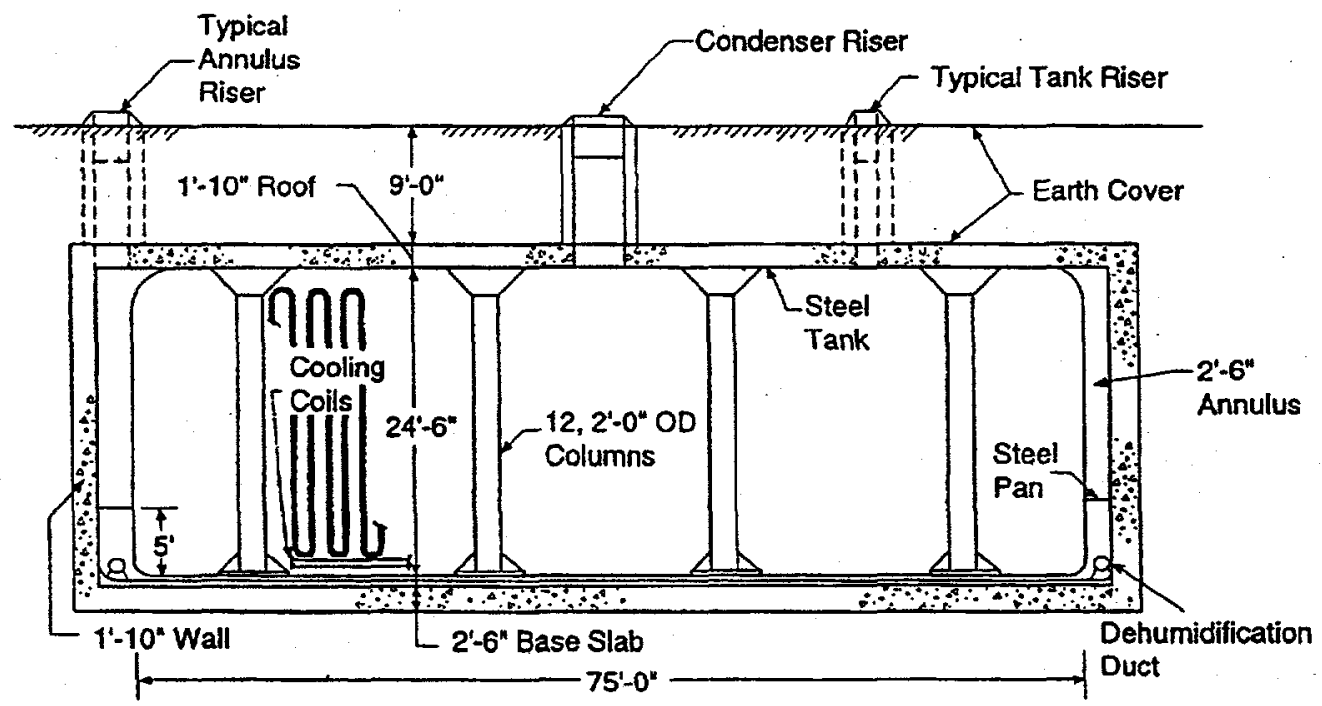

Figure 1. Cooled Waste Storage Tank, Type I (Original 750,000 Gallons).

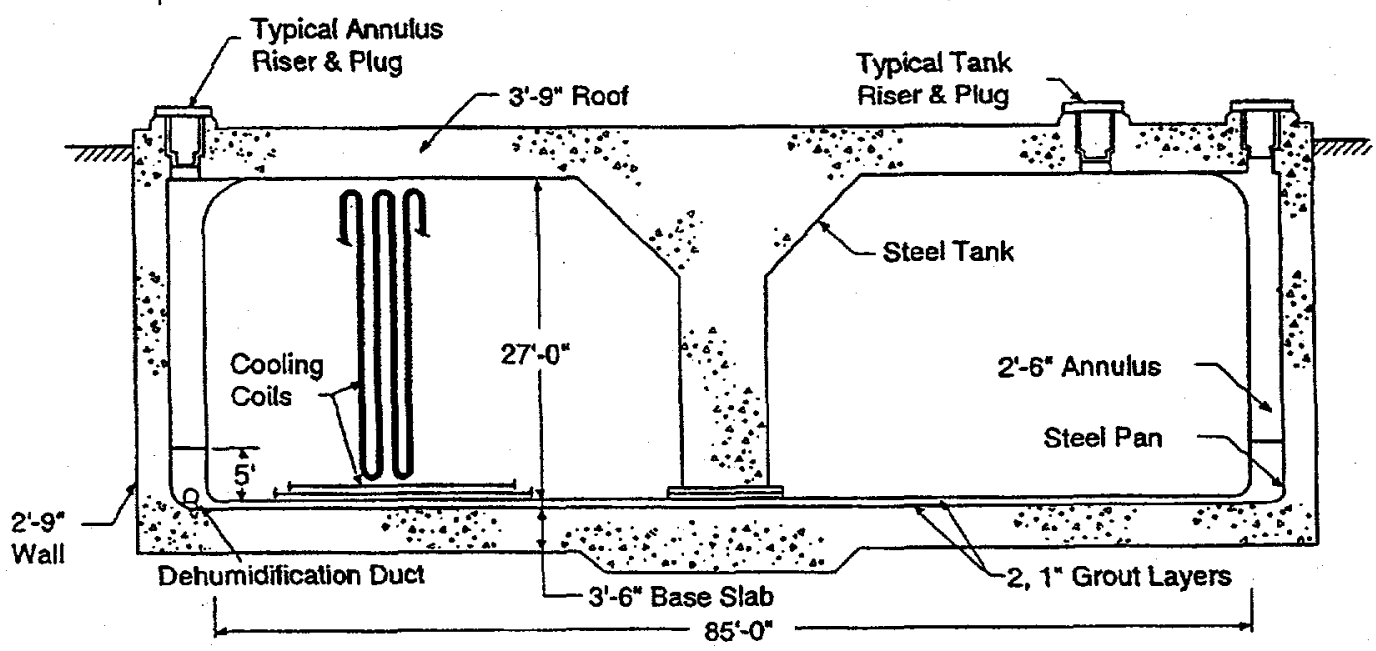

Figure 2. Cooled Waste Storage Tank, Type II (Original 1,030,000 Gallons). 


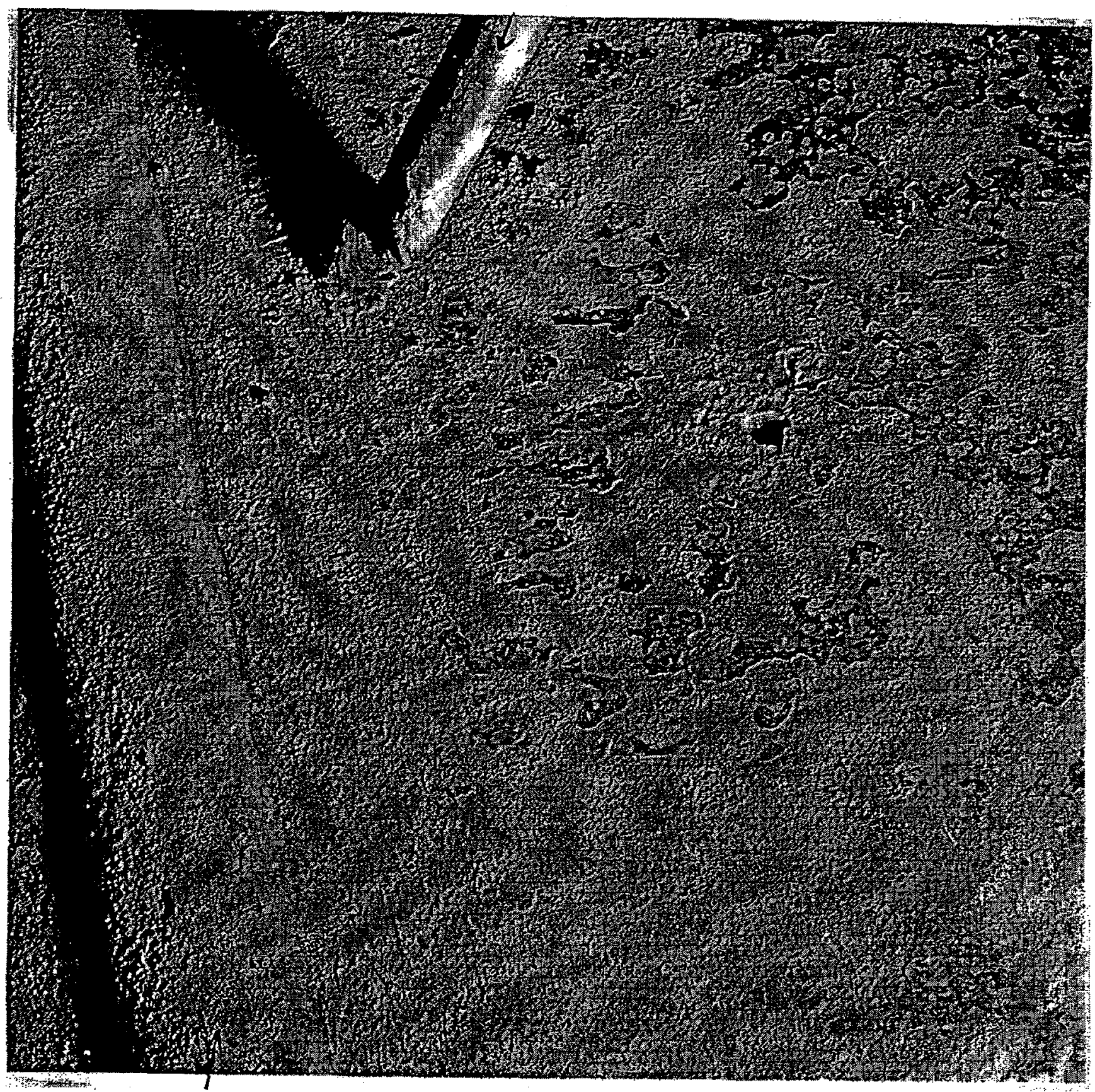

Figure 3. Severe Pitting of Tank 15 floor plates (Mag. 1.2X). 


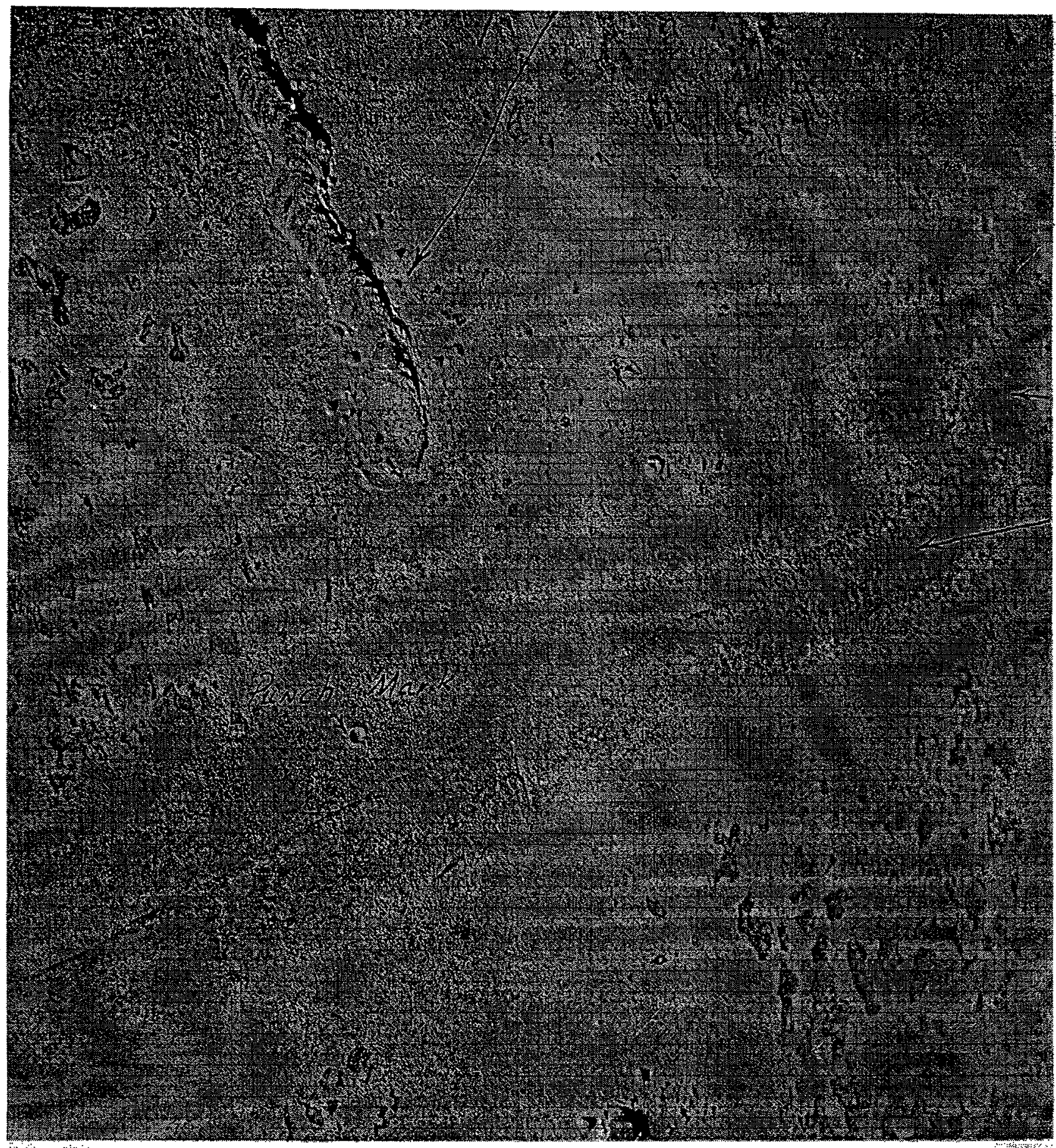

Figure 4. Punch marks for radiographic orientation adjacent to seam welds in Tank 15. Above is an example of a patch weld (Mag. 1X). 


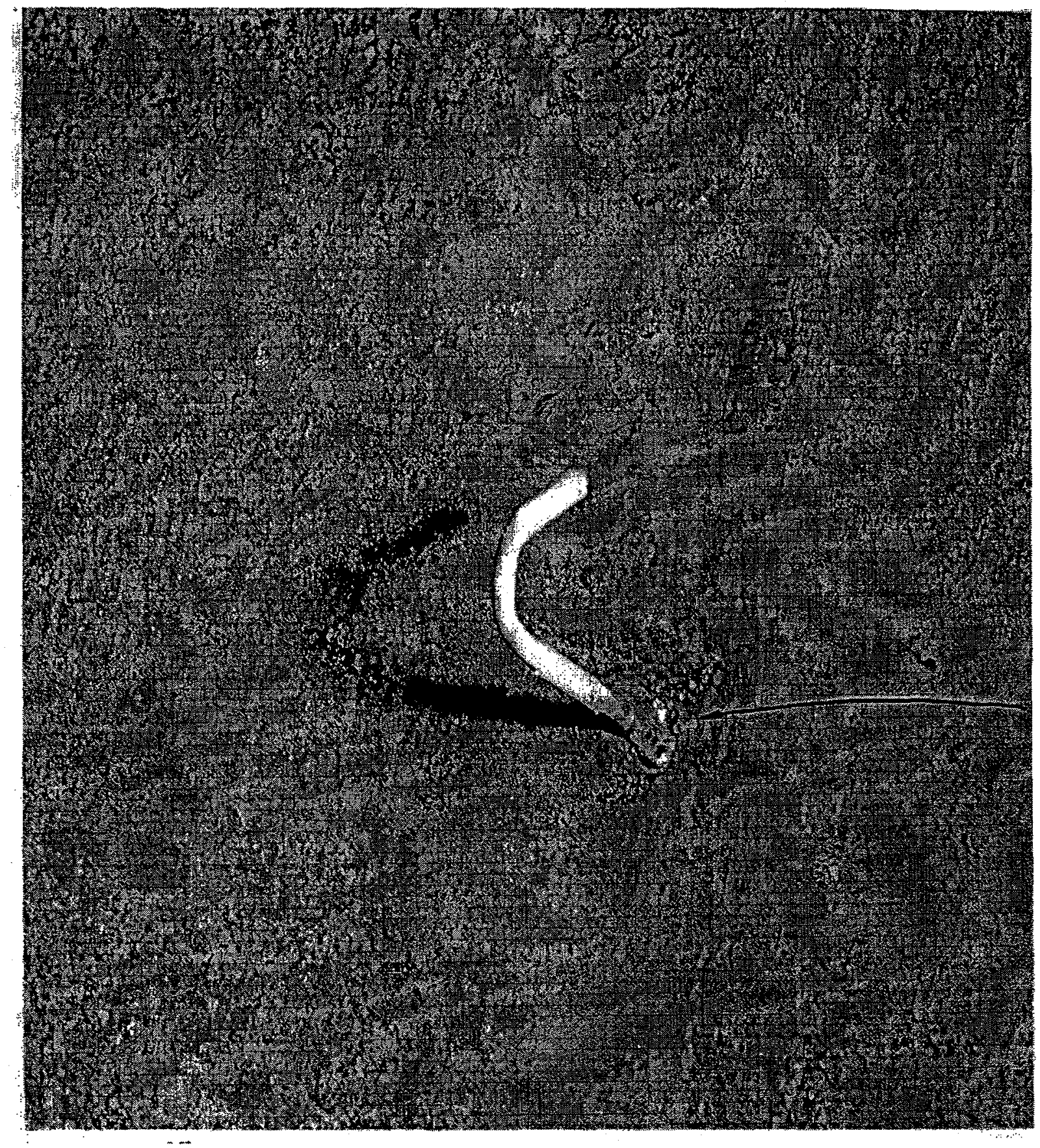

Figure 5. Weld crater near hook that was welded to the side of Tank 15 (Mag. 1X). 


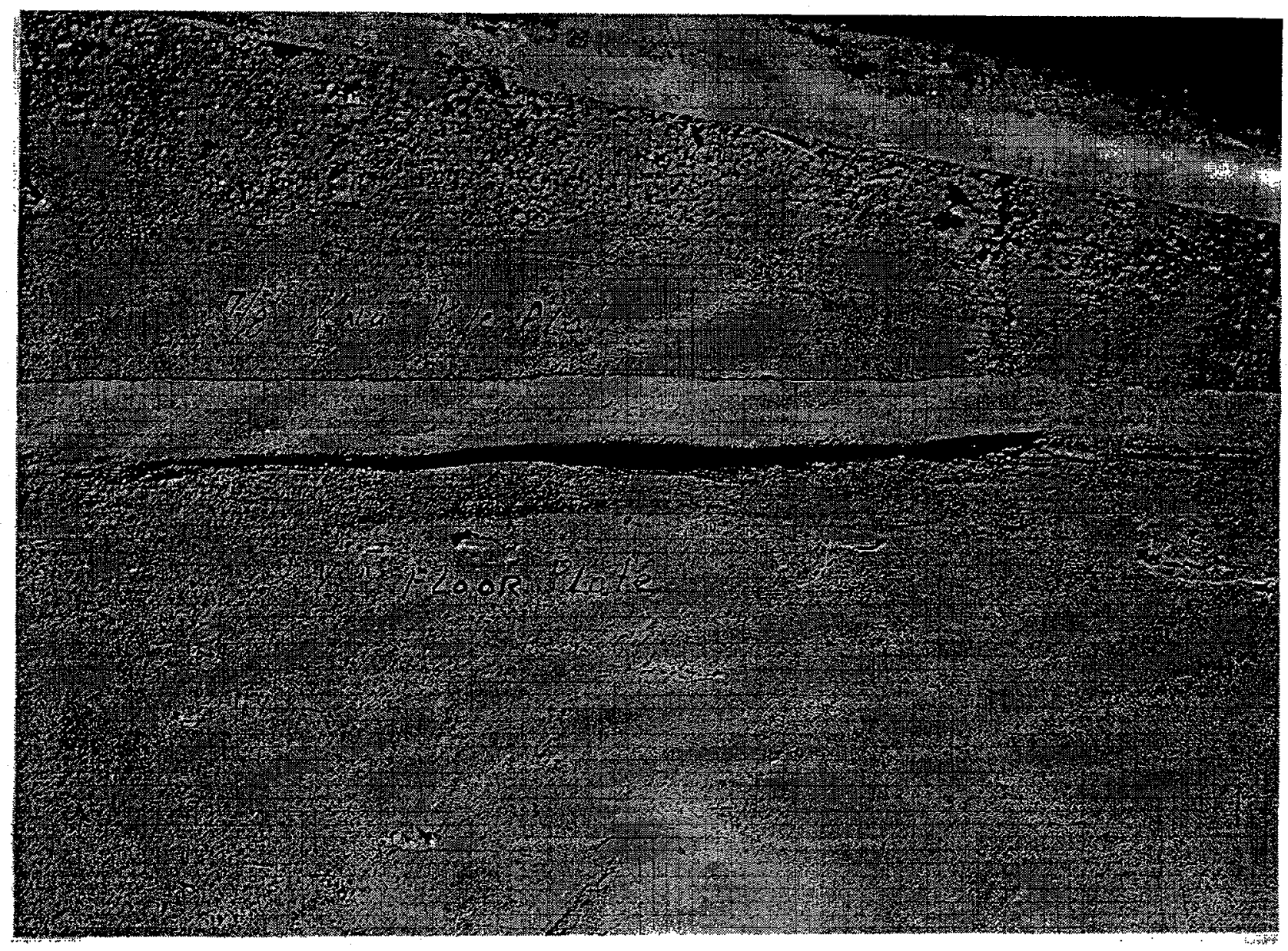

Figure 6. Partially ground out seam weld in Tank 15 (Mag. 1/3X). 


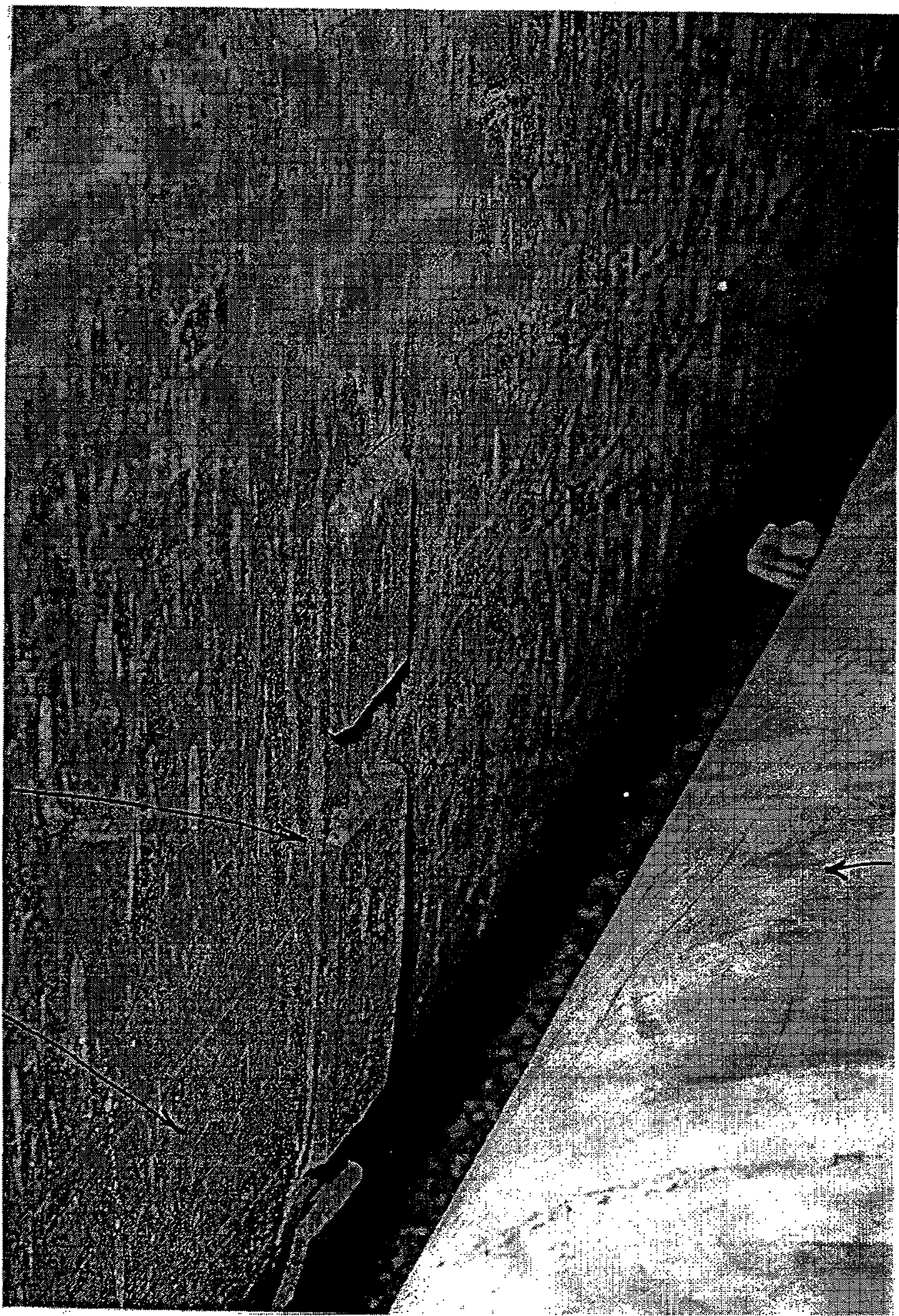

Figure 7. Back-up plates placed over vertical seam welds in Tank 15 (Mag. 1/4 X) 


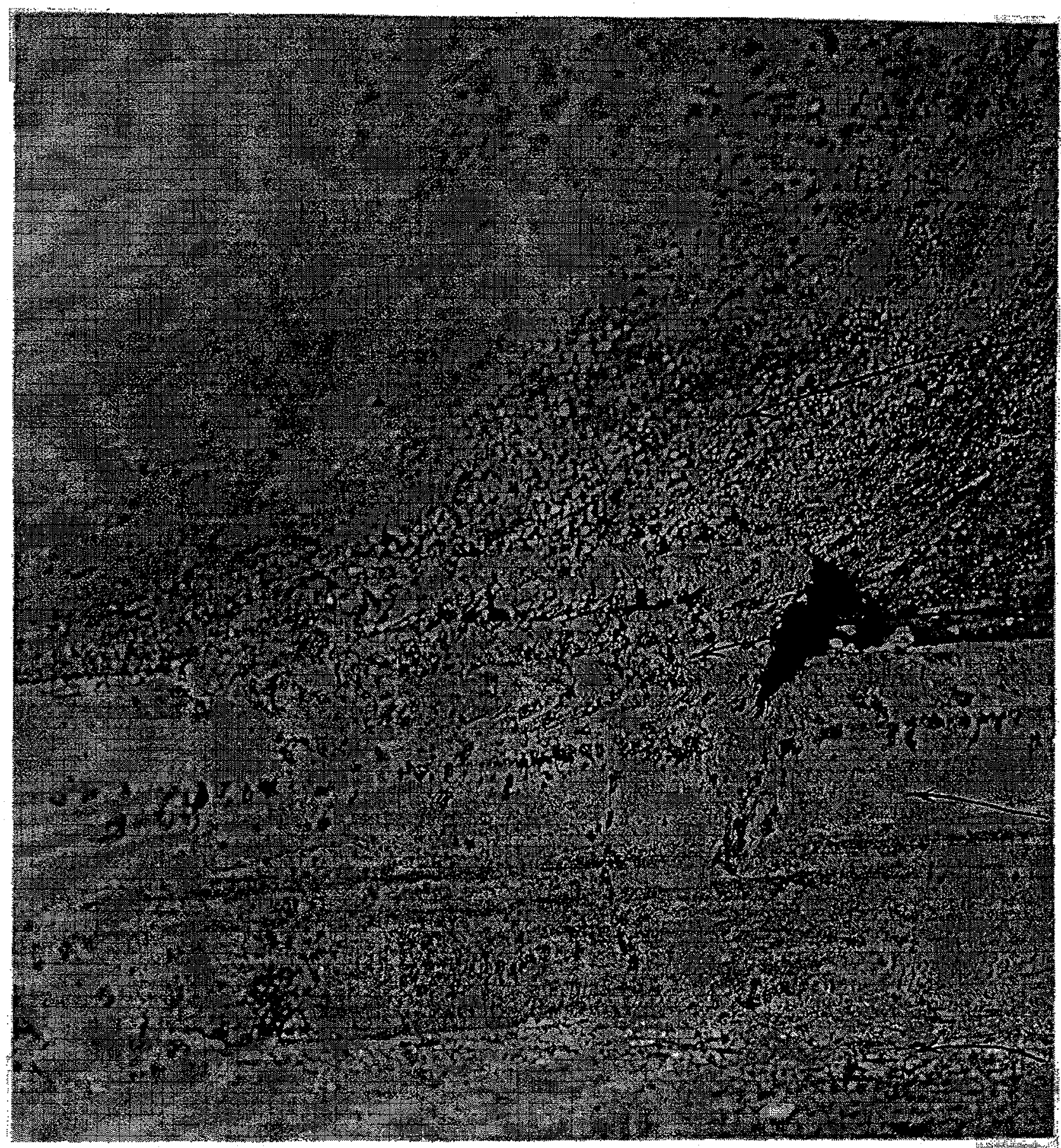

Figure 8. Heavy intermittent weld near the base of the Tank 15 knuckle (Mag. 1X). 


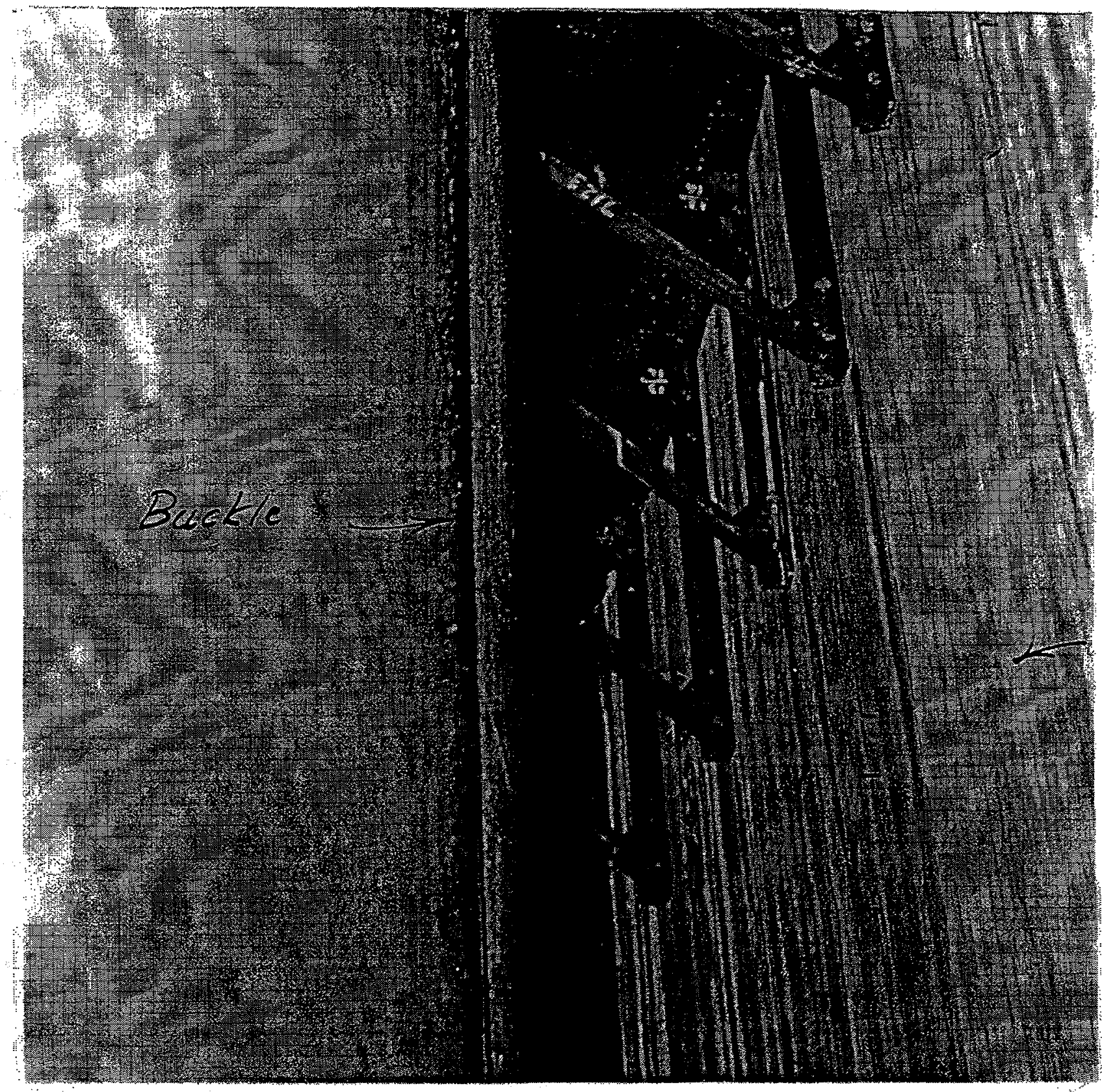

Figure 9. Severe buckle in seam weld in Tank 15 (Mag 0.1 X). 


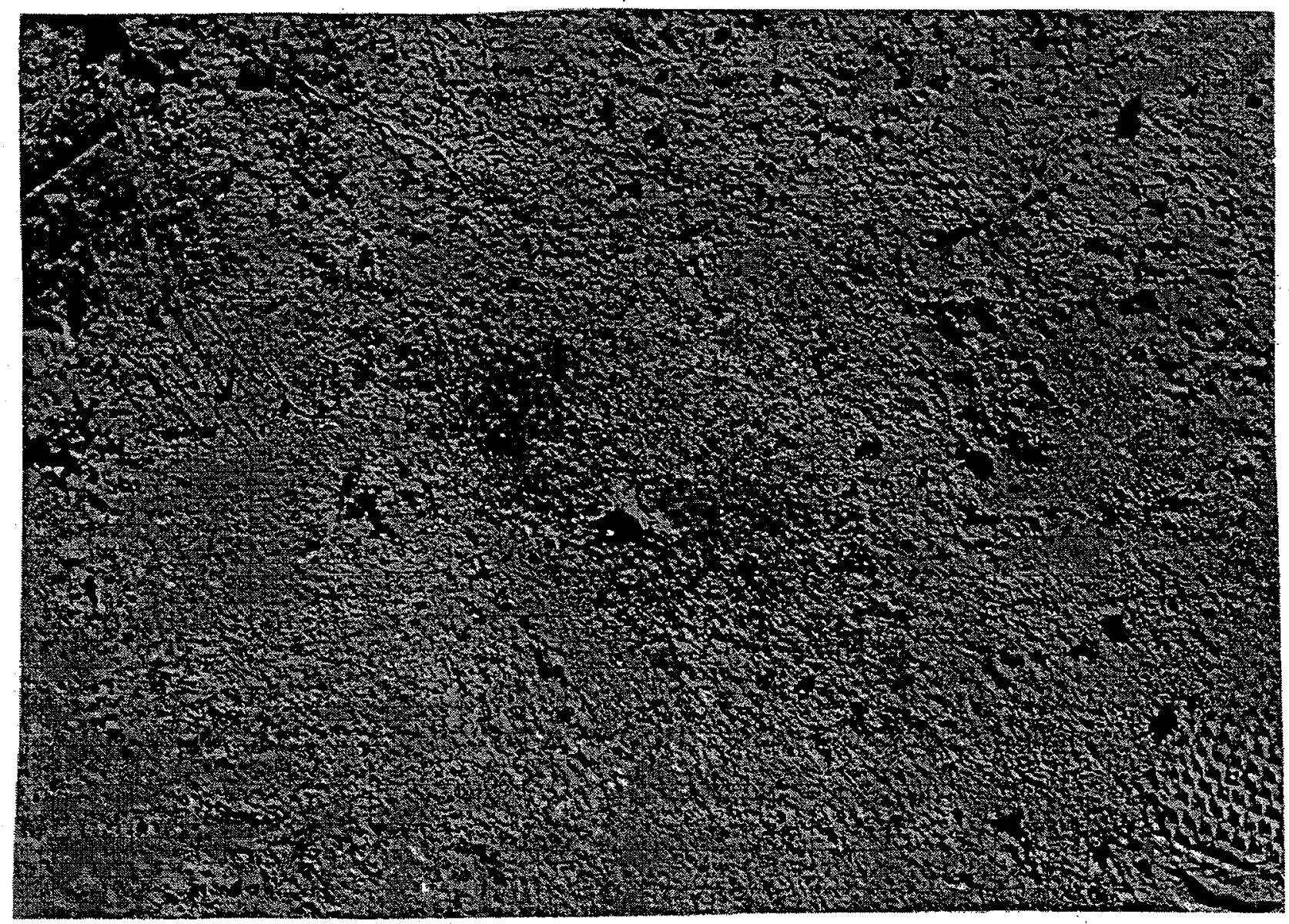

Figure 10. Corrosion pits found on the interior surfaces of Tank 4 (Mag. 1X). 


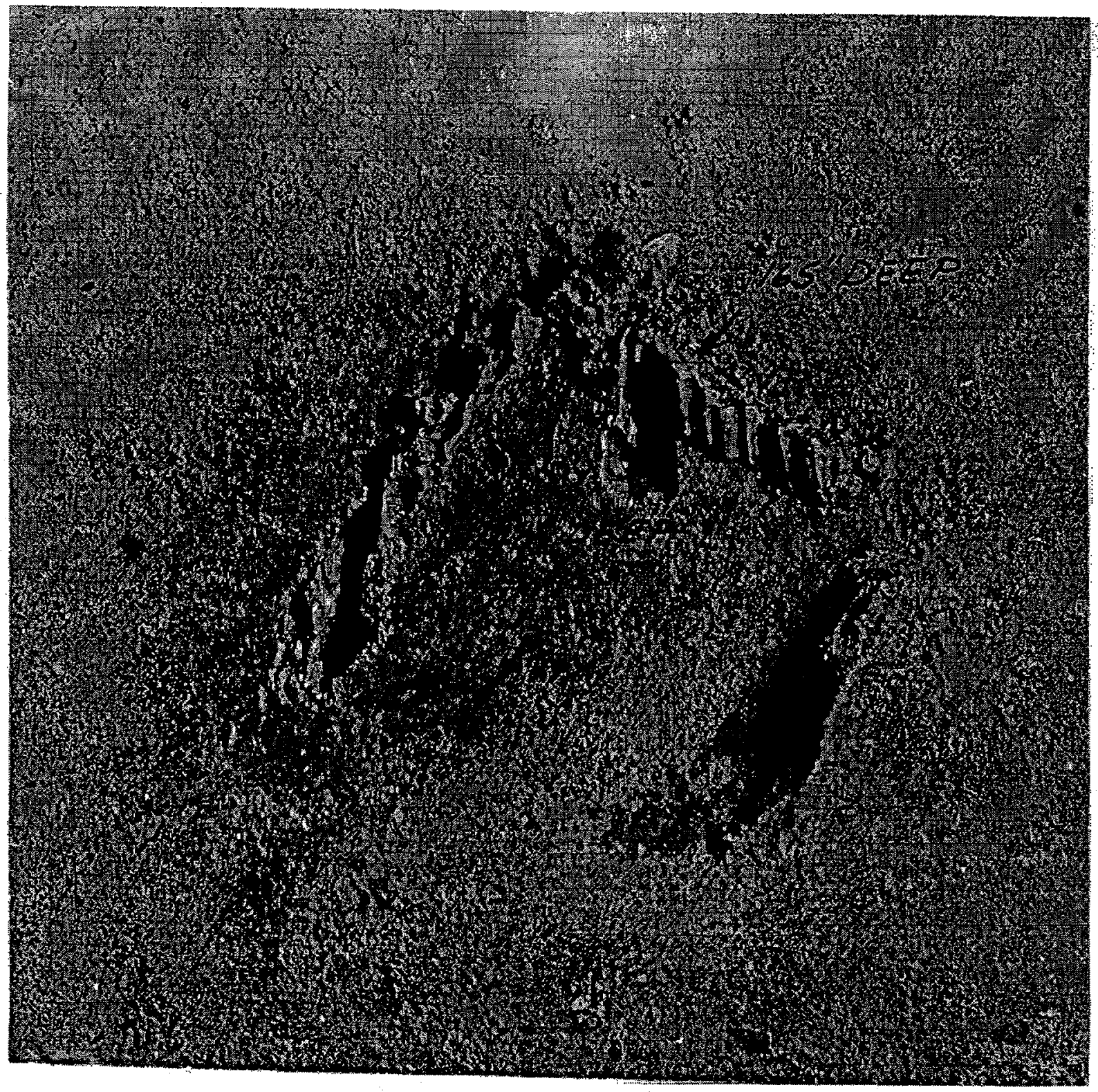

Figure 11. Gouges due to cutting torch in the bottom of Tank 4 (Mag. 1X). 


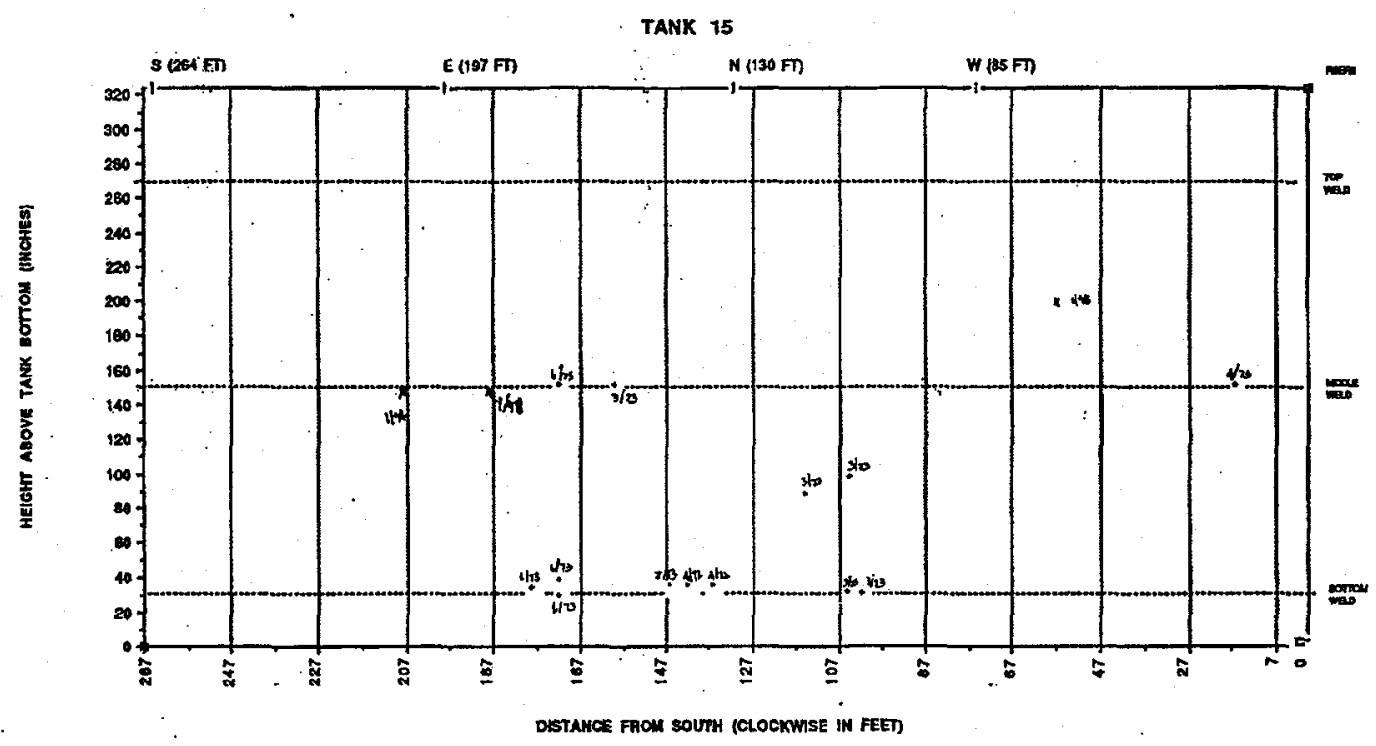

Figure 12. Wall map of Tank 15 showing the locations of leaksites. 


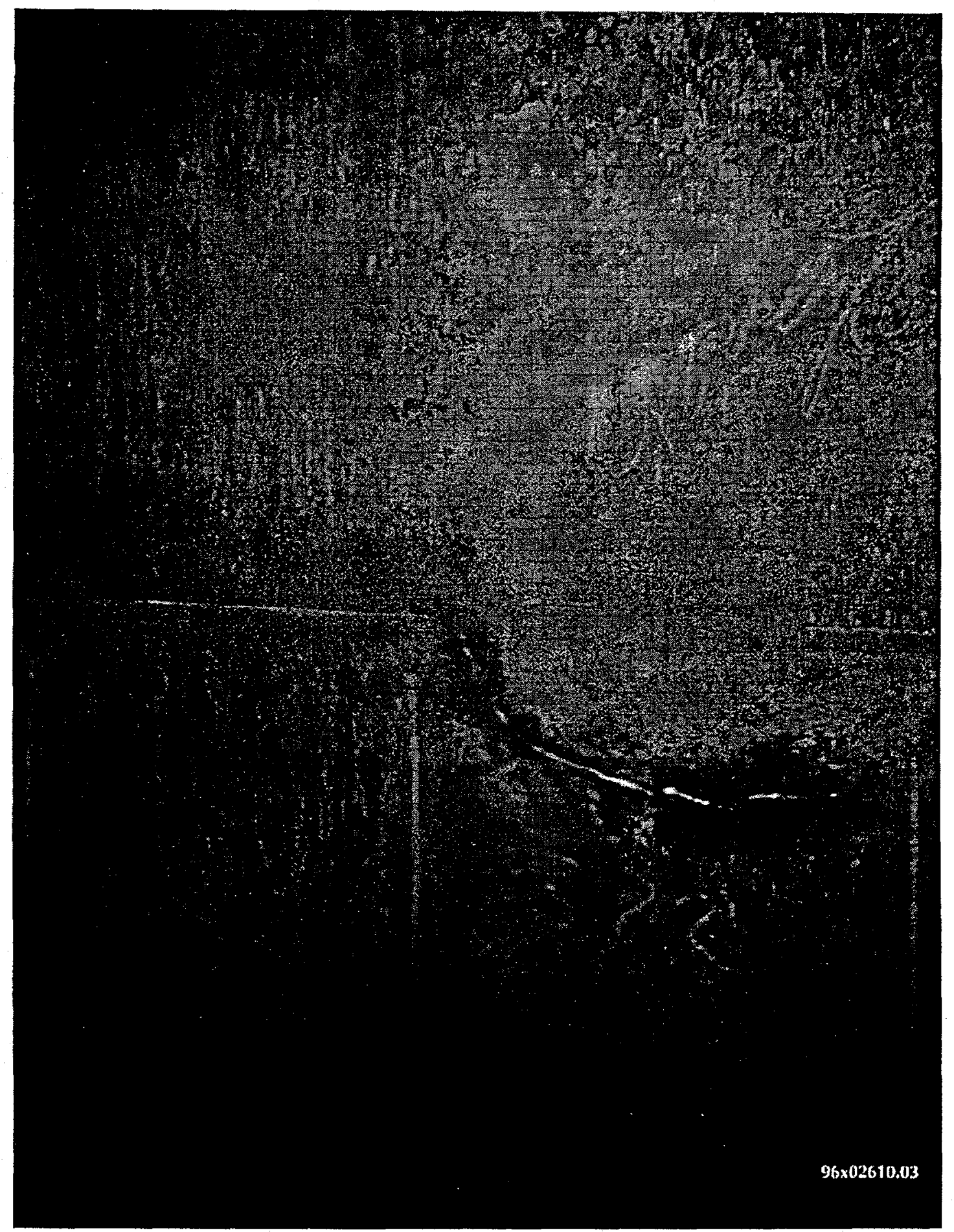

Figure 13. Crack beneath riser 207 in Tank 15. 


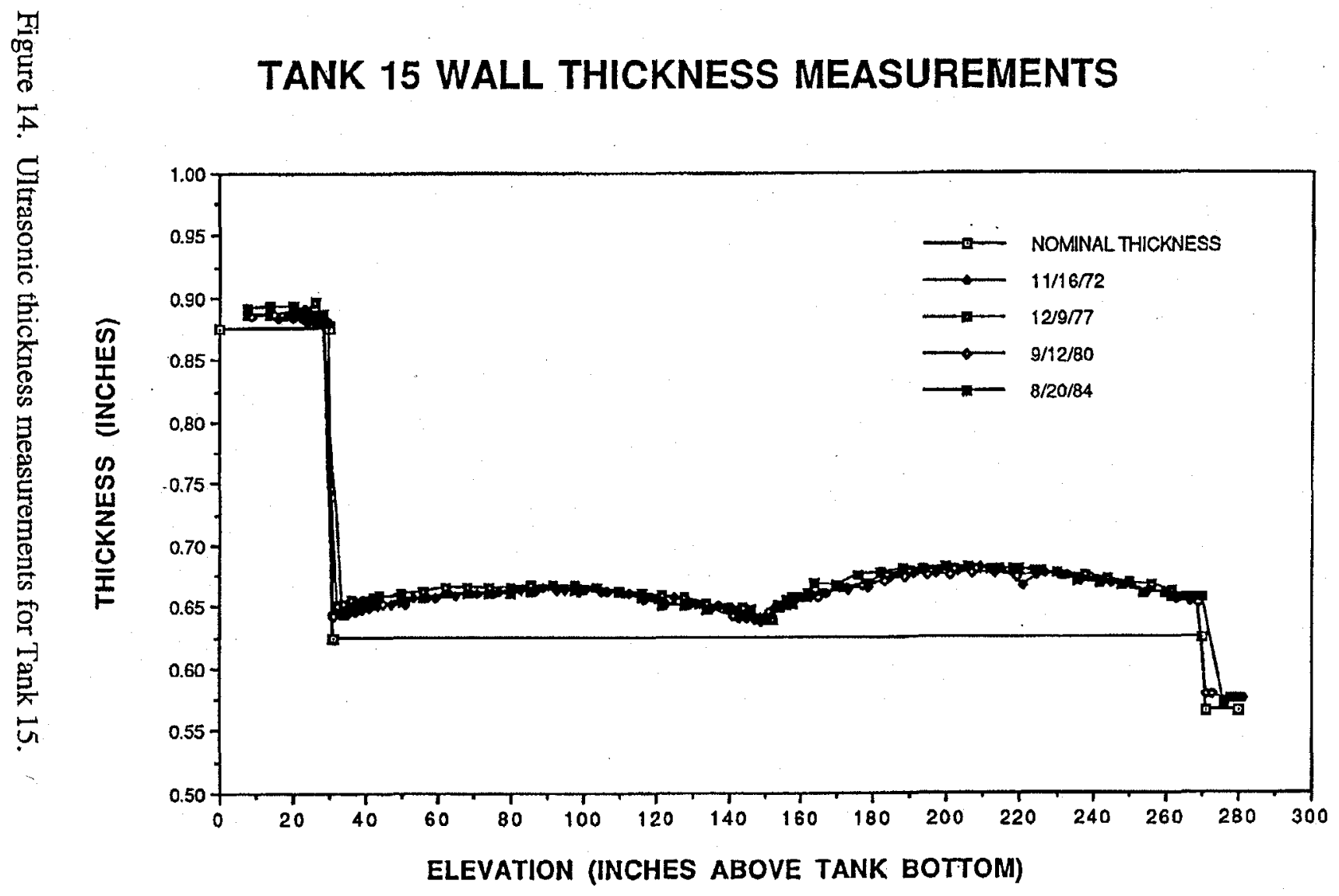




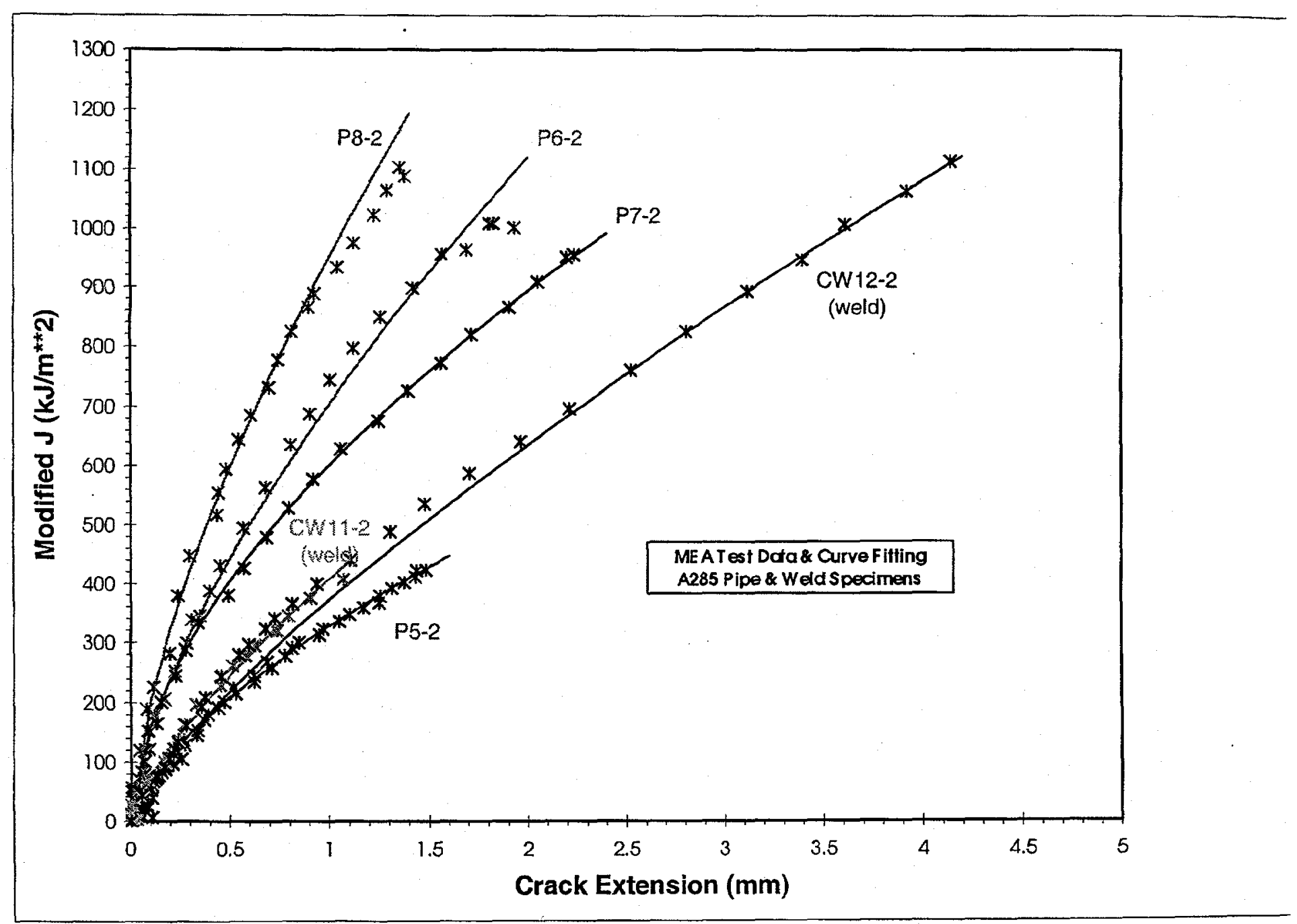

Figure 15. J modified vs. crack extension for A285 Carbon steel 


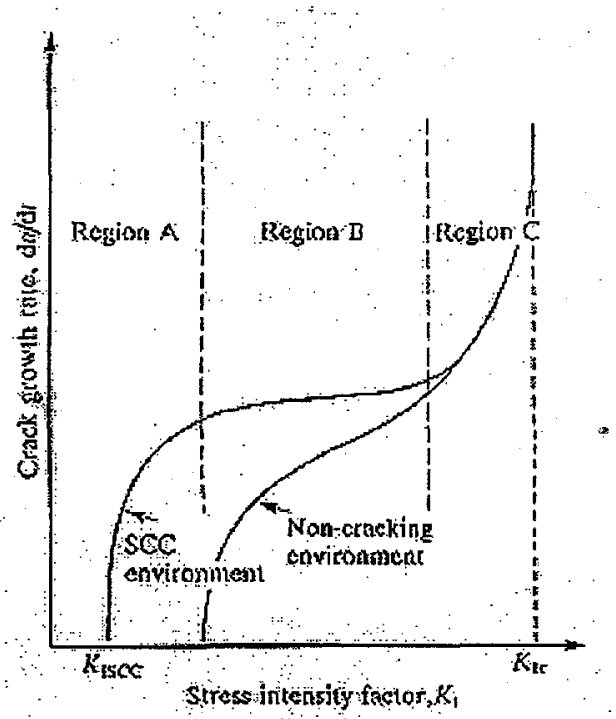

Figure 16. Testing of susceptibility to SCC by crack growth rate measurements.

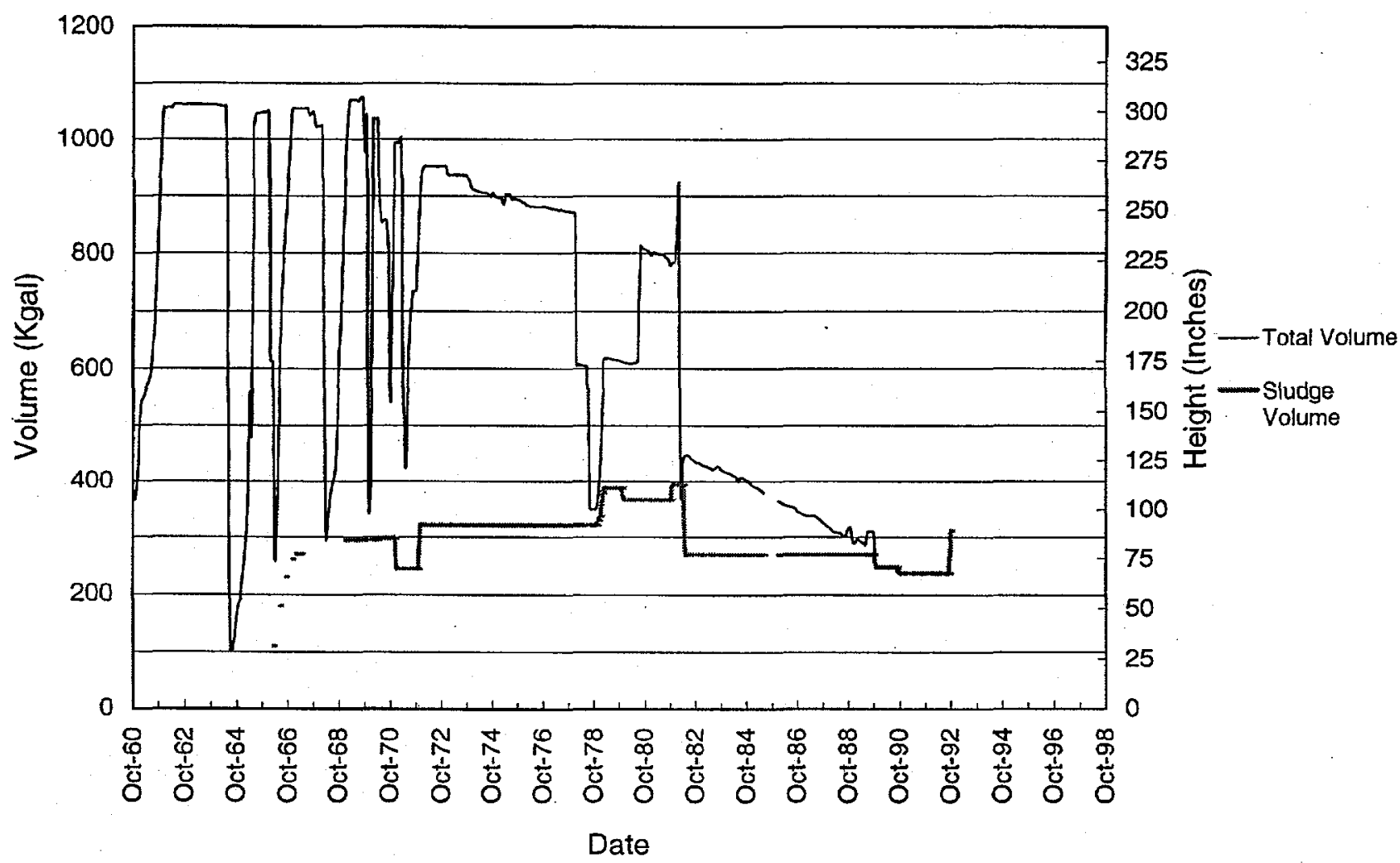

Figure 17. Waste volume and height in Tank 15. 


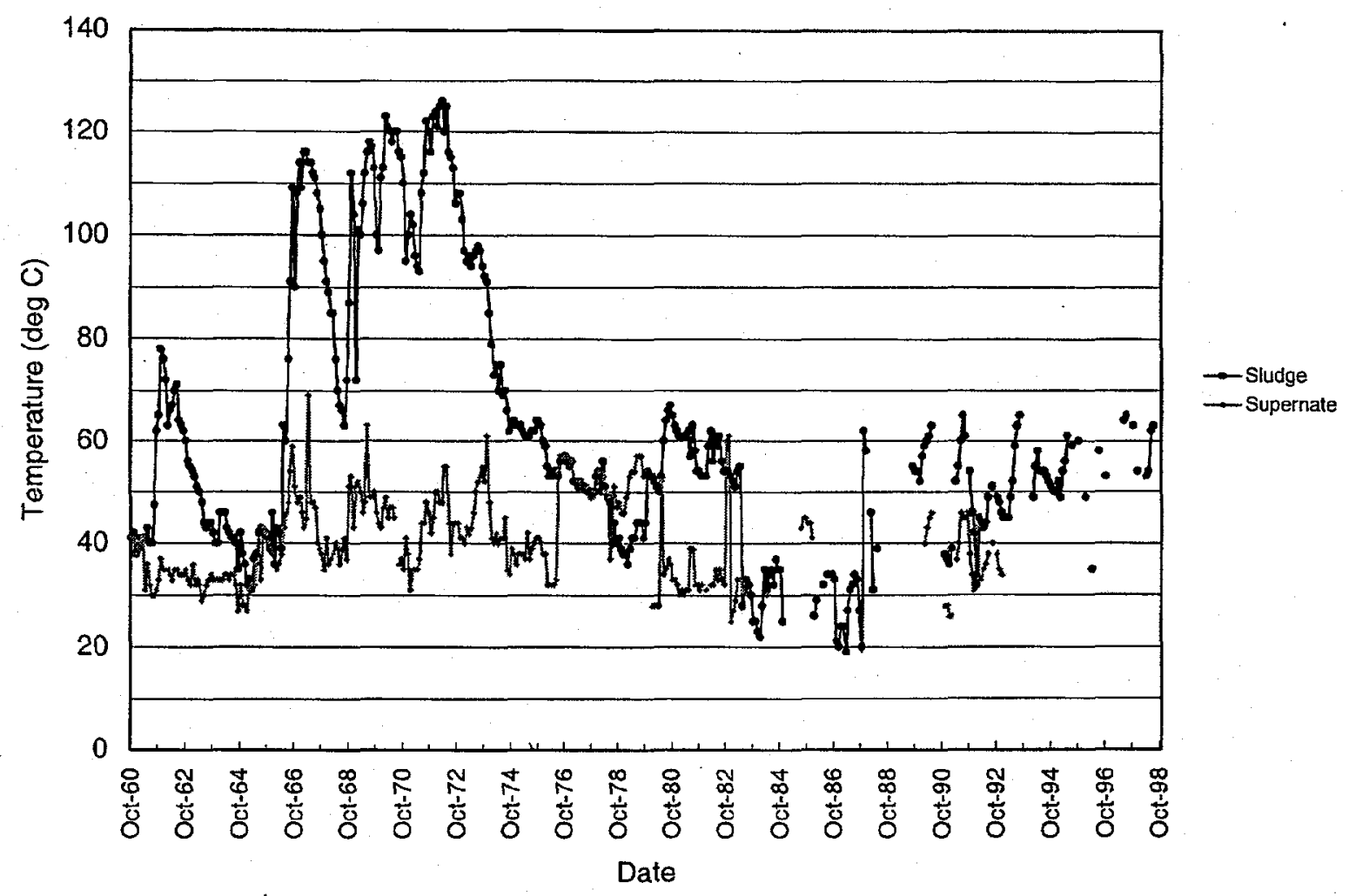

Figure 18. Tank 15 sludge and supernate temperatures. 
Distribution for WSRC-TR-98-00373

T. J. Lex, 703-H

T. M. Monahon, 703-H

V. G. Dickert, 703-H

S. M. Aleman, 703-H

T. C. Temple, 703-H

B. L. Lewis, 703-H

J. N. Dewes, 703-H

B. J. Shapiro, 703-H

M. S. Shurrab, 703-H

E. Nomm, 703-H

W. L. Tamosaitis, 773-A

S. D. Fink, 773-A

C. R. Wolfe, 773-A

T. L. Capeletti, 773-41A

N. C. Iyer, 773-A

P. E. Zapp, 773-A

R. L. Sindelar, 773-41A

P. S. Lam, 773-41A

B. J. Wiersma, 773-A

W. N. Kennedy, 730-1B

G. B. Rawls, 730-1B

G. E. Mertz, 730-1B

C. D. Cowfer, 730-B

TIS, 773-52A (4)

MTS Files, 773-41A 